يهنهبندى كانىهاى رسى غالب در خاكهاى استان اصفهان و ارتباط آنها با اقليم و مواد مادرى

\author{
فاطمه خياميم"، حسين خادمى و شمس اله ايوبى'

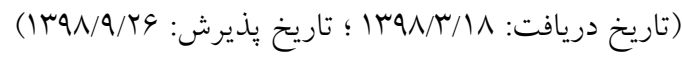

جكيده

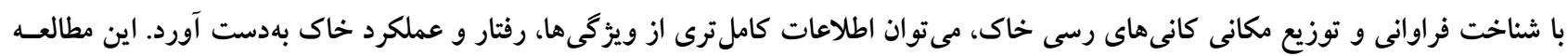

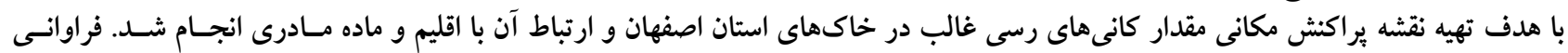

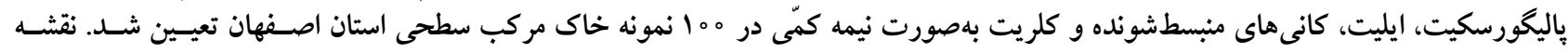

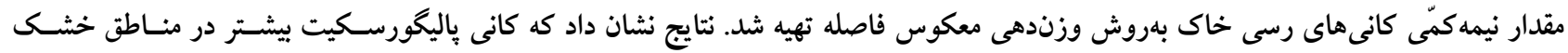

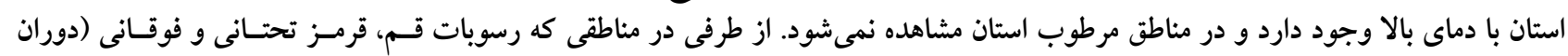

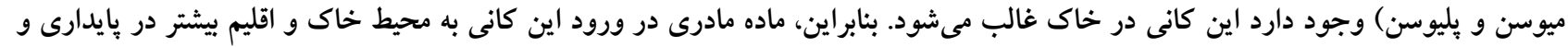

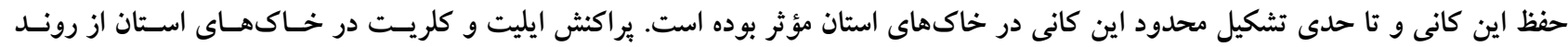

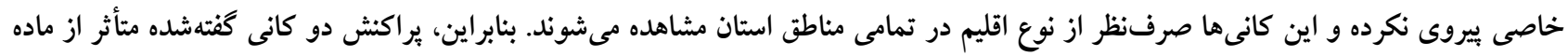

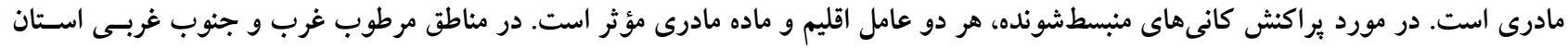

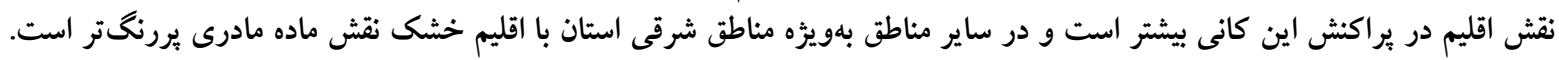

وازههاى كليدى: باليكورسكيت، خاكهاى استان اصفهان، كانىهاى رسى، كلريت 


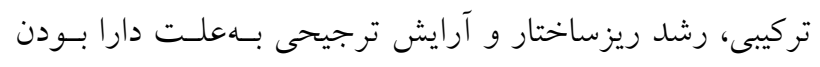

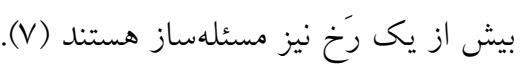

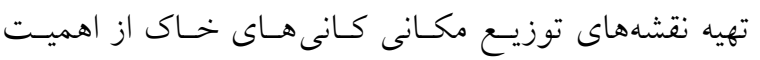

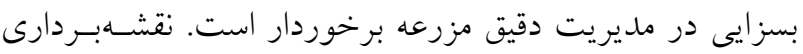

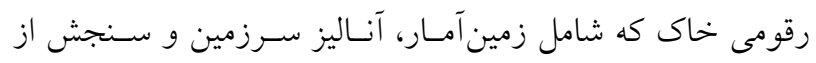
دور مىشود براى ييشبينى مكانى تغييرات خاك بهكـار مسىرود

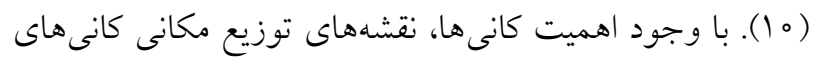

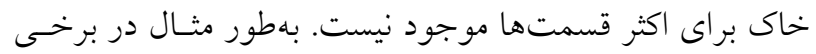
از مطالعات، كانى هاى خاك را بهصورت محلى تشخيص دادهاند

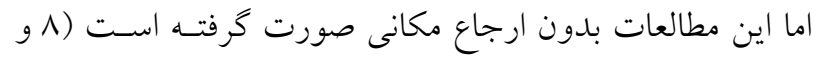
(YV

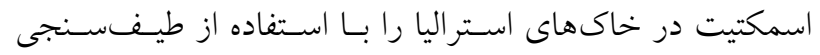

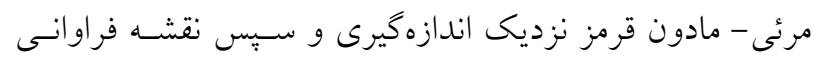
نسبى و توزيع هر يكى از كانى ها را بهصورت رقومى تهيه كـرد.

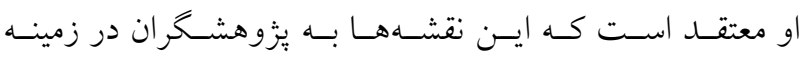

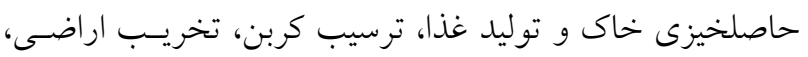
مدلسازى اقليم و تغييرات اقليم كذشته كمك زيـادى مسى كنــد.

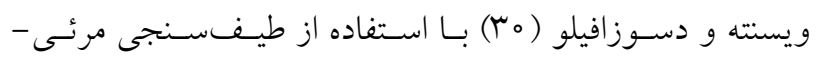

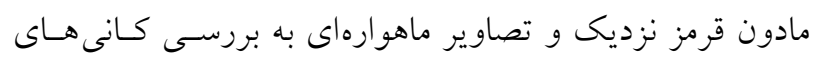

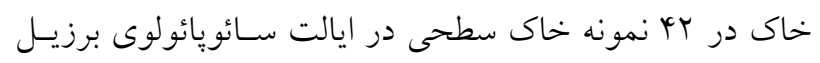

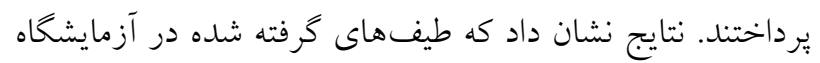

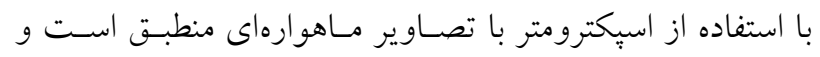

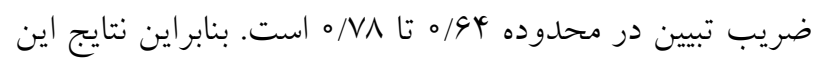

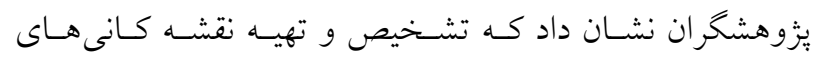

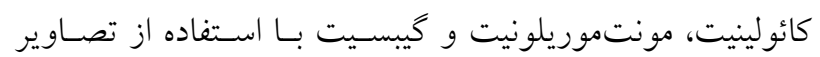
ماهوارهاى امكانيذير است. مولدر و همكاران (YY) از دادههـاى

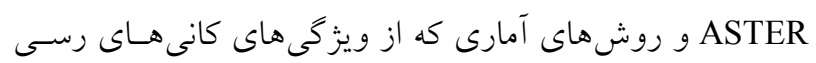

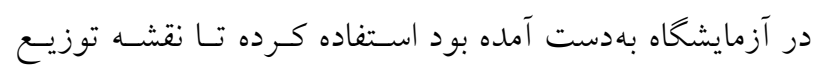

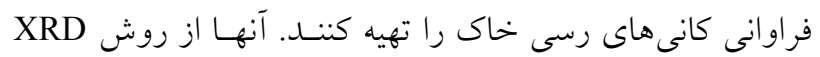

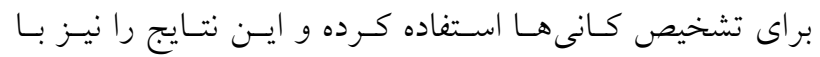

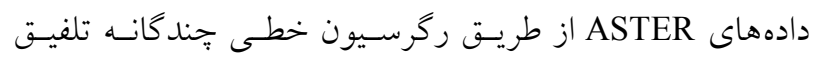

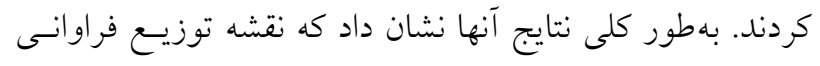

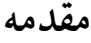

كانى هاى رسى جزء اصلى خاك هسـتند و بـهـعنـوان بخشـى از

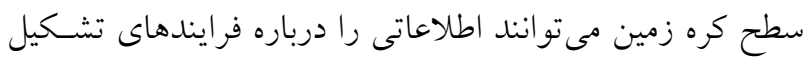

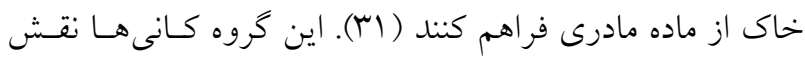

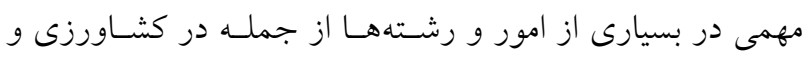

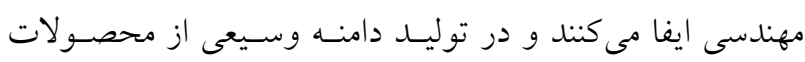

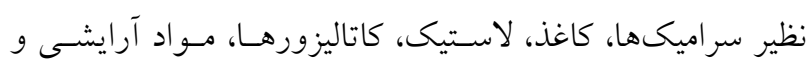

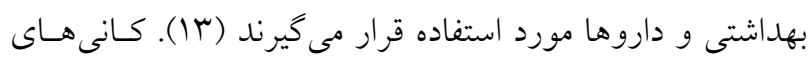

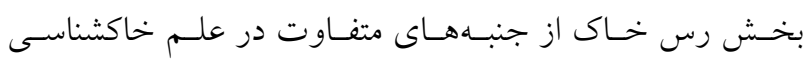

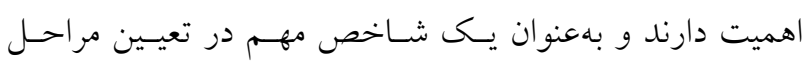

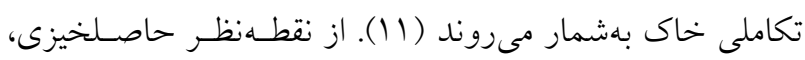
كانى هايى كه داراى ظرفيت تبادل كاتيونى بيشتر هستند بهاعنسوان

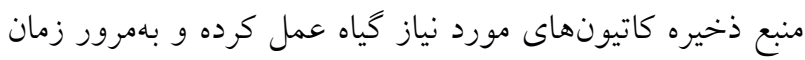

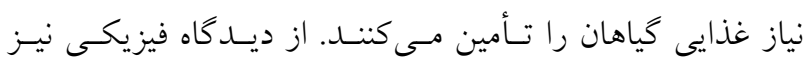

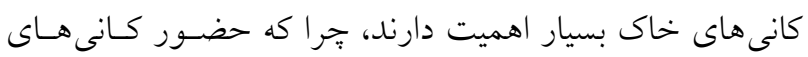

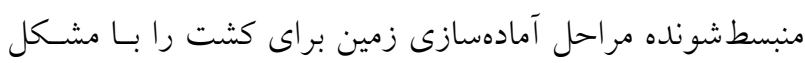

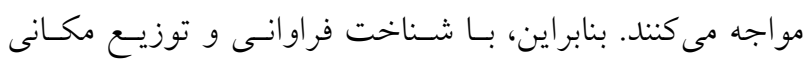

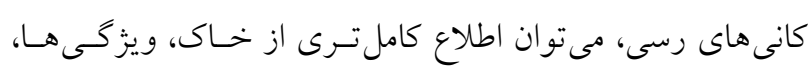

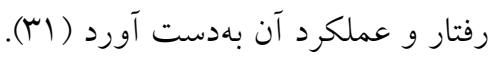
تعيين دقيق مقدار كانىهاى رسى مختلف بسيار مشكل است

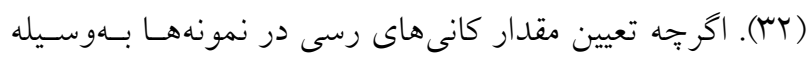

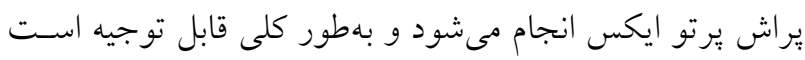

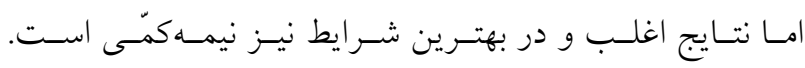

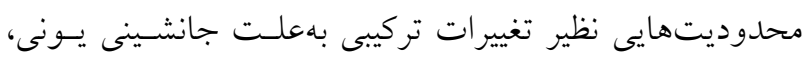
درجات مختلف نظم يا بى نظمى هاى ساختارى و بهعبارتى تغيير

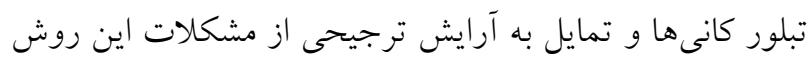

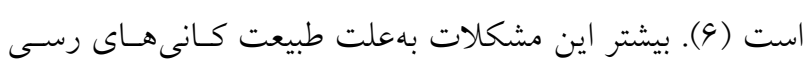

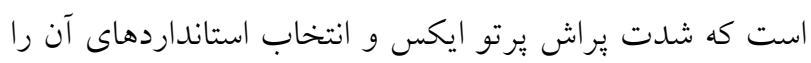
با مشكل مواجه مى سازد. صرفنظر از همه اين مشكلات، مقدار

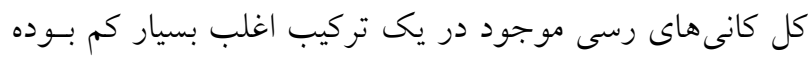

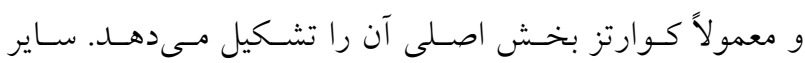

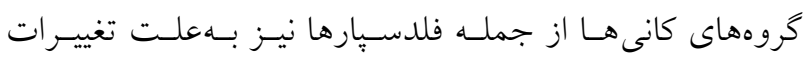




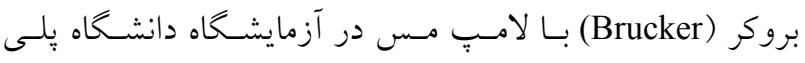

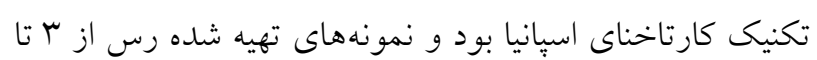

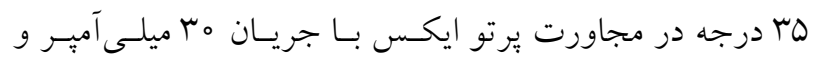

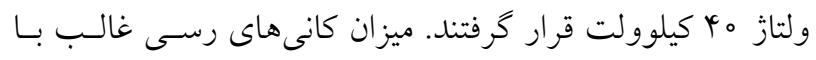

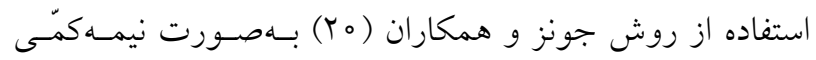

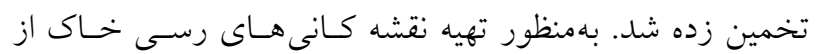
روش وزندهـى معكـوس فاصـله (IDW) اسـتفاده شـــ (ه). ارزيابى خطاى تخمين مدل با استفاده از دو بارامتر ميانخين خطا

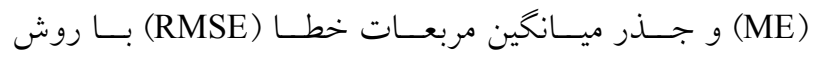
اعتبارسنجى متقاطع انجام شد.

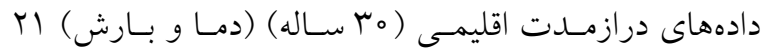
ايستخاه سينويتيك استان، از اداره هواشناسى استان اصفهان تهيـهـ

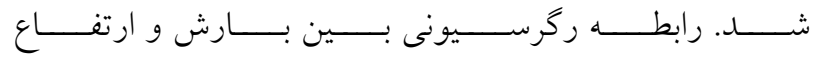

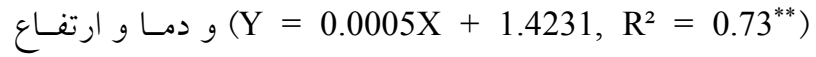
در ايستخاههـاى (Y = -0.0063X + 26.054, R $\left.=0.95^{* *}\right)$ سينويتيك استان برقرار شد. با توجسه بـهـ صـحت و معنسىدارى

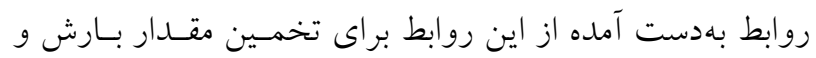

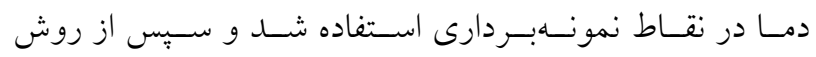

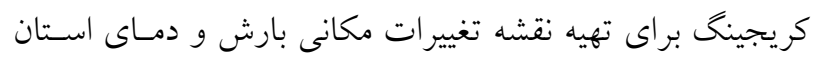

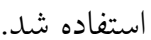
بهمنظور بررسى تأثير مواد مادرى در نقاط نمونسهبــــاردى از

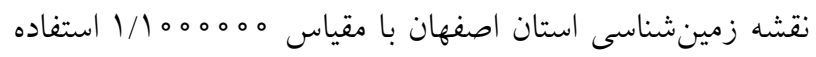

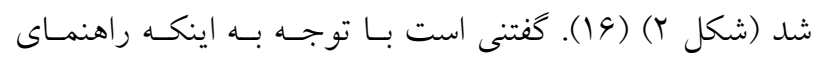

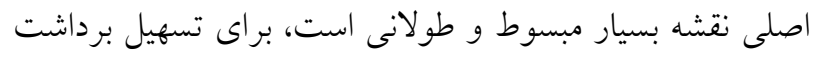

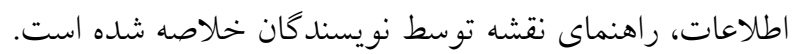

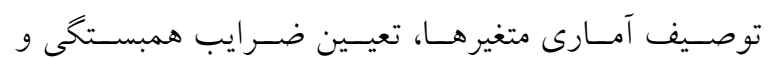

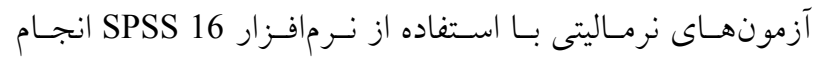

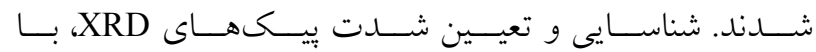
اسـتفاده از نـــرم|فـزار Xpert High Score Plus صــورت

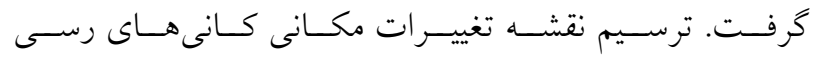

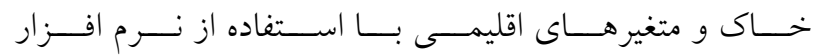
ArcGIS 10.2
كانى هاى بـهدسـت آمـــه بــراى ميكـا، اسـمكتيت و كائولينيـت

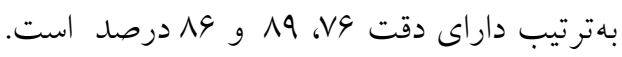
با توجه به آنجه درباره اهميت كانى هاى خاك و تهيه نقشـه. ير اكنش آنها كفته شد، تاكنون مطالعه جامعى در رابطه تغييـرات

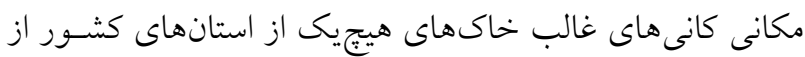

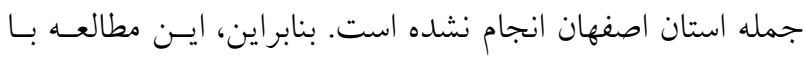
هدف تهيه نقشه يراكنش مكانى كانى هاى منبسطشونده، ايليـت،

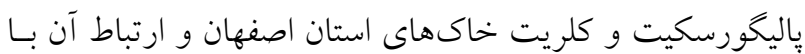

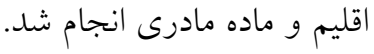

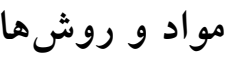

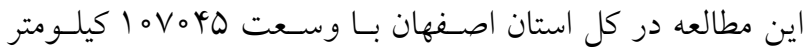

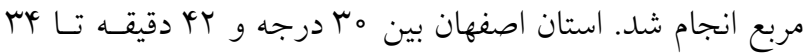

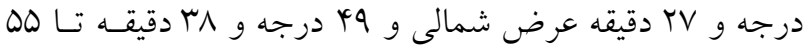
درجه و r T دقيقه طول شرقى در بخش مركزى ايران واقع شـده است (IV). بهمنظور نمونهبردارى خاك، منطقه مطالعاتى بهطسور

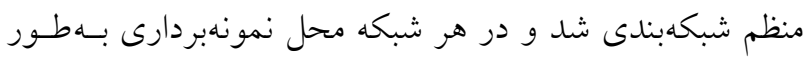

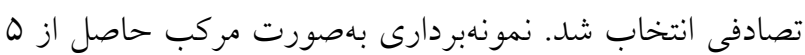

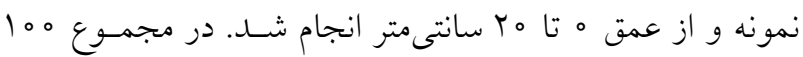

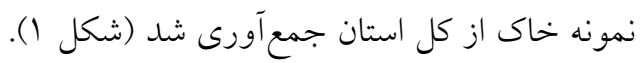
pH

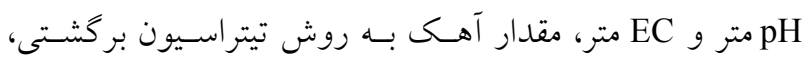

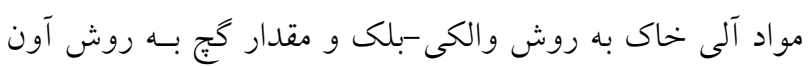

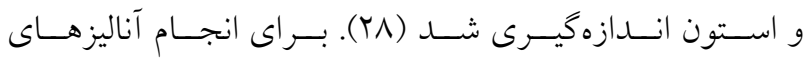

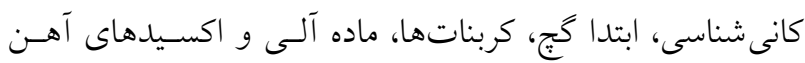
نمونههاى خاك حذف شد و يس از جداسازى شن از سـيلت و رس بـهوسـيله الـى، جداسـازى رس خـاك از سـيلت توسطط

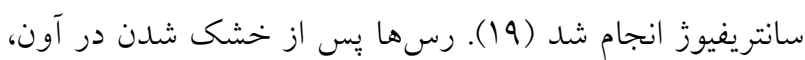

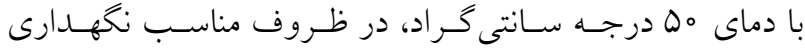
شدند. تيمارهـاى اشـباع بـا منيـزيم، اشـباع بـا منيـزيم و اتسيلن

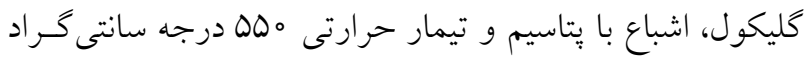

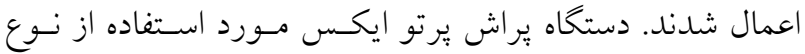




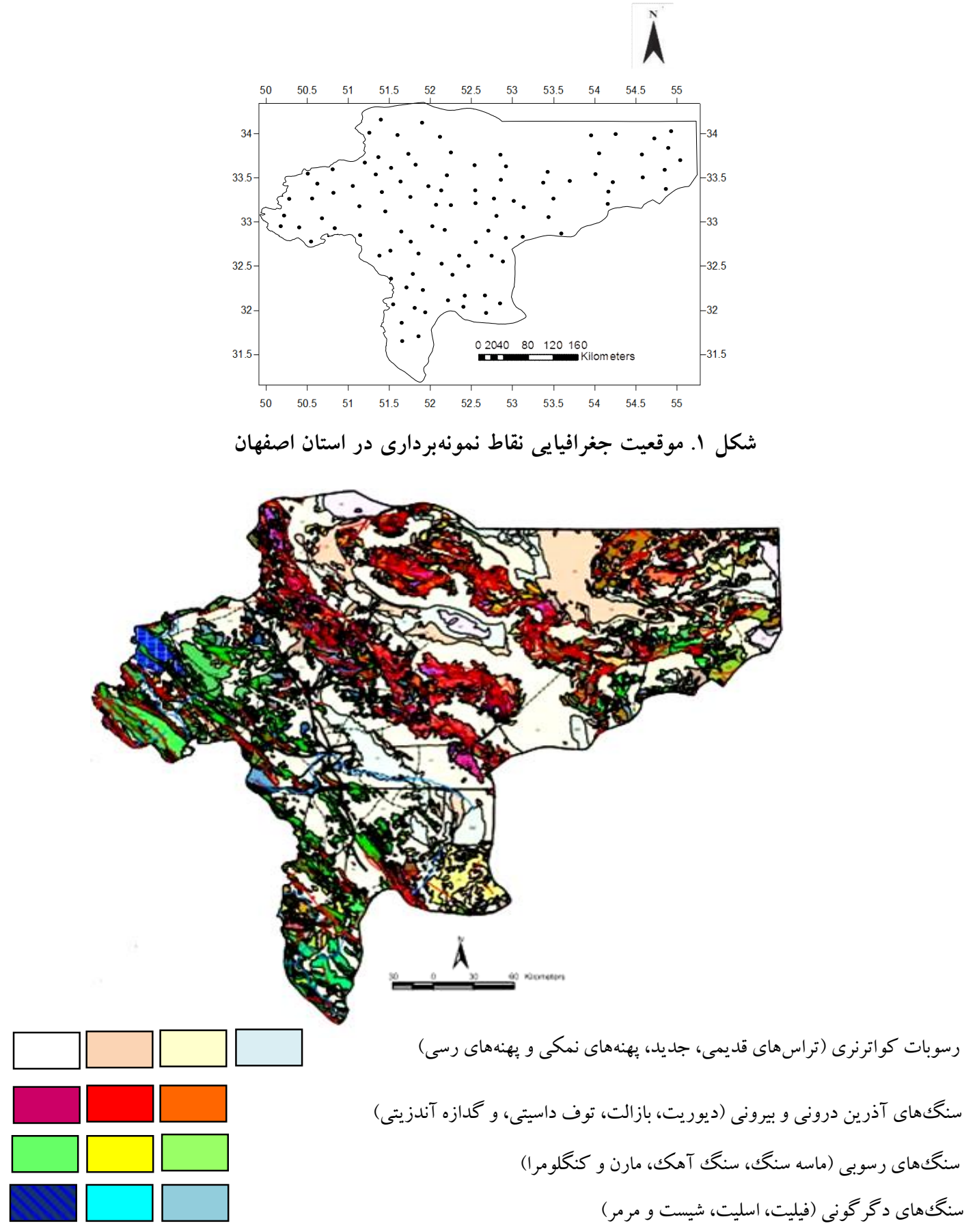

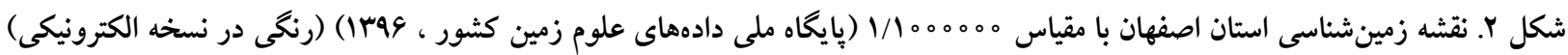

حد زيادى مشخص مى كنند. رايجتـرين منشـأ تعيسين دادههـاى

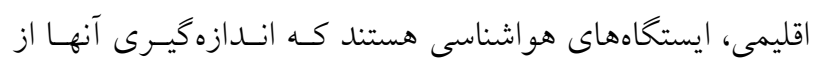

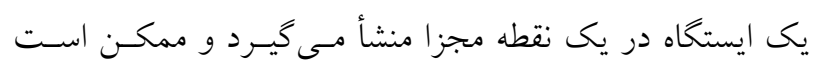

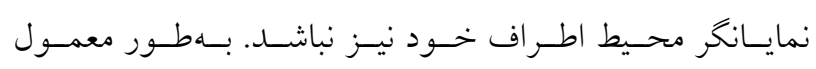

نتايج و بحث

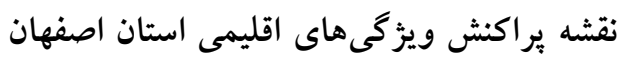

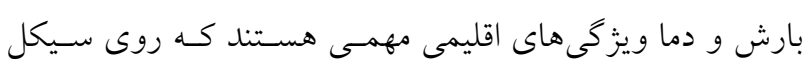

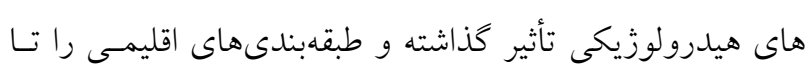




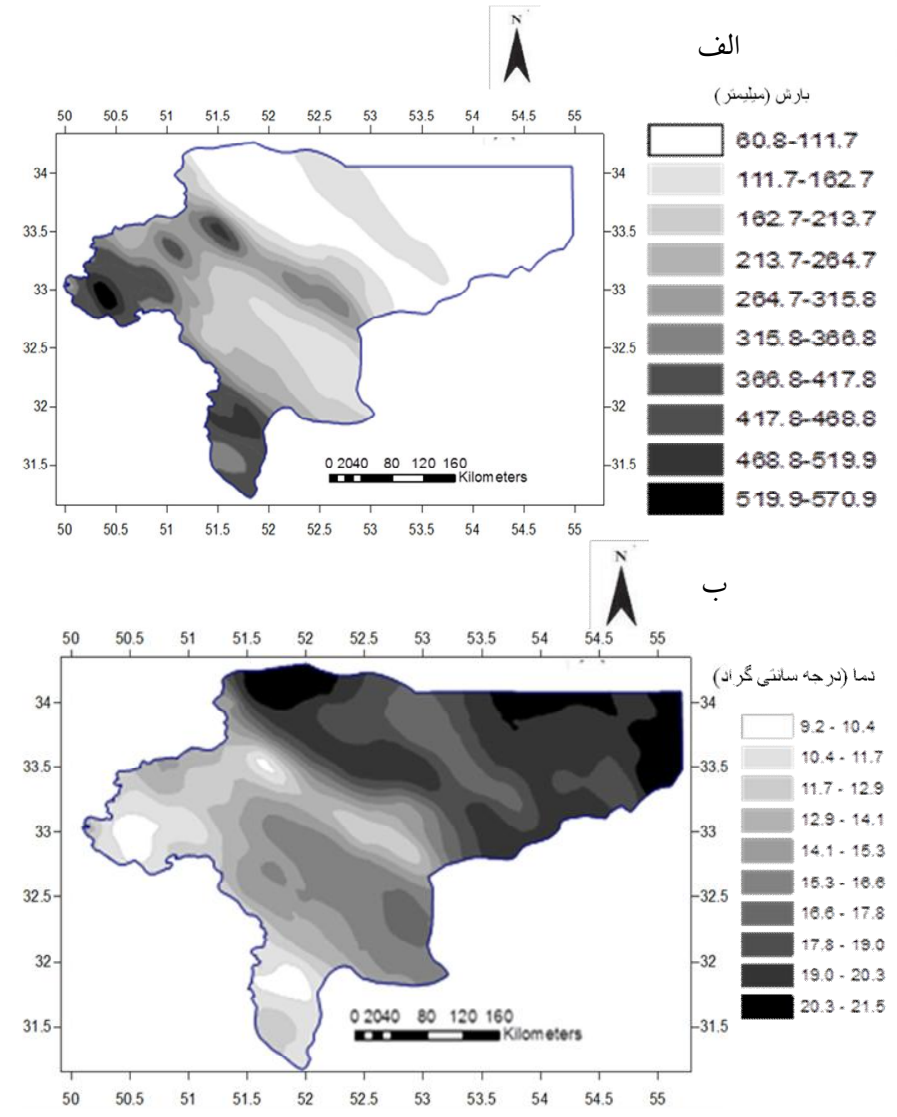

شكل r. الف) تغييرات مكانى ميانخين بارش و ب) دماى سالانه استان اصفهان

يُزوهشكران يادآور شدند كه با توجه به اينكـهـ بـارش و دمـا دو

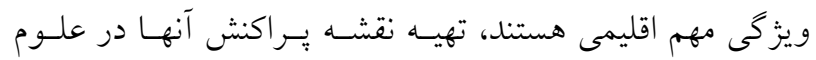

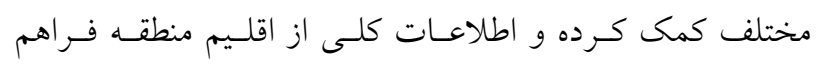
مى سازد. شكل r (الف و ب) نقشه تغييـرات مكـانى بــارش و دمـاى

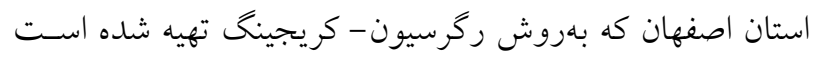

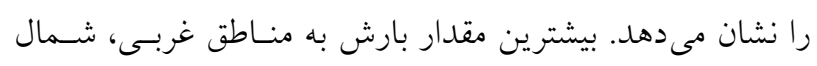

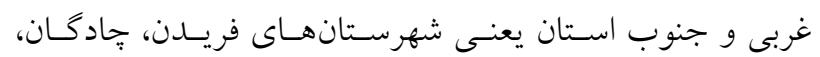

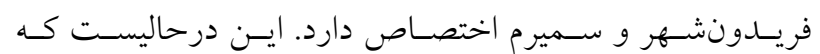

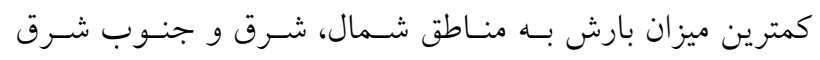

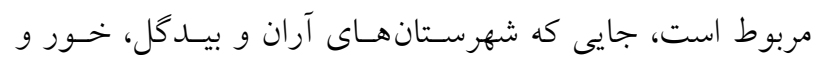

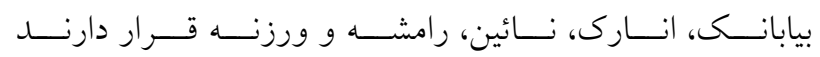

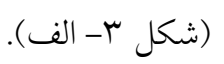

تغييرات مكانى دماى استان اصفهان در شـكل rآ- ب نشـان داده شده است. روند كاملاً معكوس آنجه كه درباره بارش كفته
اندازه كيرىهاى نقطهاى از نزديكترين ايستخاه هواشناسـى بــه

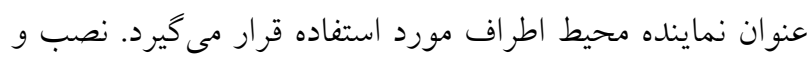

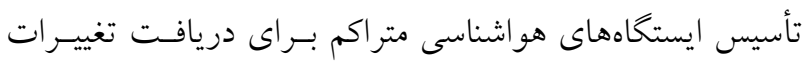

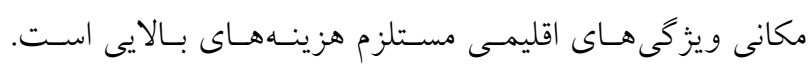

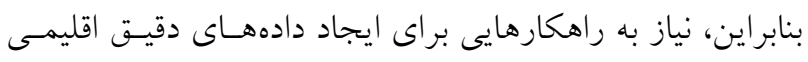

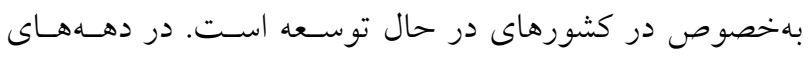

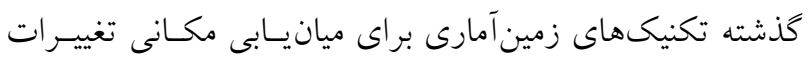

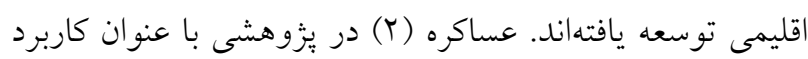

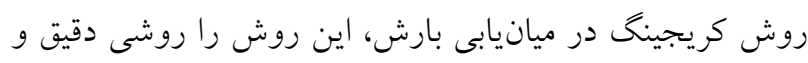

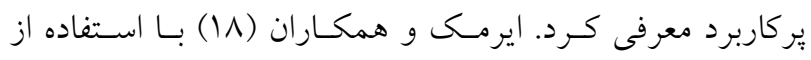

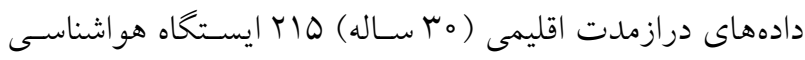

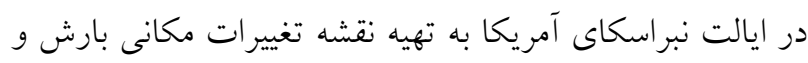

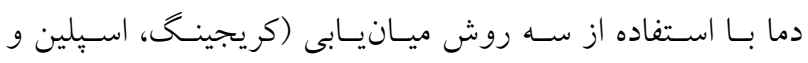
وزندهى عكس فاصله) برداختند. نتايج آنها نشان داد كـه هـيجيج

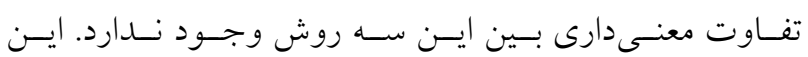


جدول ا. توصيف آمارى ويزّكىهاى خاك در ه 10 نمونه مورد بررسى در آناليزهاى كانىشناسى

\begin{tabular}{|c|c|c|c|c|c|c|c|c|c|}
\hline $\mathrm{KS}$ & كشيد كى & جو جلى & انحر اف معيار & ميانخين & حداكثر & حداقل & واحد & تعداد & متغير \\
\hline $1 / 9$ & $4 / 0$ & $Y / 0$ &.$/ 0$ & $\circ / 4$ & $T / Y$ & $\circ / 0$ & $\%$ & 100 & ماده آلى \\
\hline $1 / 0$ & $-0 / 9$ & $0 / 9$ & $I V / \Lambda$ & $T Q / T$ & $9 \mathrm{~V} / \mathrm{V}$ & $0 / r$ & $\%$ & 100 & آهك \\
\hline$r / Y$ & $9 / \pi$ & $T / \mu$ & $V / T^{c}$ & $\Delta / V$ & ऍ $/ \nu$ & $\%$ & $\%$ & 100 & گَج \\
\hline $1 / 1$ & $-0 / 9$ & $\circ / 0$ & $9 / \mathrm{V}$ & $1 r / 9$ & $r q / r$ & $T / \circ$ & $\%$ & 100 & رس \\
\hline$\circ / \Lambda$ & $1 / 0$ & $\circ / \wedge$ & $10 / V$ & $M_{1 / V}$ & $10 / 9$ & $Q / \circ$ & $\%$ & 100 & سيلت \\
\hline $0 / 9$ & $-0 / 1$ & $-\circ / \uparrow$ & $1 / / 4$ & $\Delta Q / Y$ & $19 / 9$ & $0 / Y$ & $\%$ & 100 & شن \\
\hline$r / \Lambda$ & $09 / \circ$ & $9 / 9$ & $\Lambda / \Lambda$ & $r / \Lambda$ & $\vee \wedge / \vee$ & $\circ / 1$ & $\mathrm{dS} / \mathrm{m}$ & 100 & $\mathrm{EC}$ \\
\hline $0 / 9$ & $r / 9$ & $\%$ & $\circ / r$ & $\mathrm{~V} / \mathrm{\Lambda}$ & $\Lambda / v$ & $V / I$ & - & 100 & $\mathrm{pH}$ \\
\hline
\end{tabular}

جدول Y. توصيف آمارى درصد كانىهاى خاى در 0010 نمونه مورد مطالعه

\begin{tabular}{|c|c|c|c|c|c|c|c|c|c|}
\hline $\mathrm{KS}$ & كشيدكى & جولكى & انحراف معيار & ميانخين & حداكثر & حداقل & واحد & تعلداد & متغير \\
\hline$T / 0$ & $\mathrm{r} / \Lambda$ & $1 / 9$ & $10 / 0$ & $r \Lambda / r$ & $M / \circ$ & $1 / 0$ & $\%$ & 100 & كانى هاى منبسطشونده' \\
\hline$\circ / \wedge$ & $\circ / \mu$ & $-0 / 1$ & $9 / T$ & $r q / r$ & $0 \circ / 9$ & $T / T$ & $\%$ & 100 & ايليت \\
\hline$r / 1$ & $r / 4$ & $r / r$ & $1 Y / 9$ & $\mathrm{~V} / \mathrm{I}$ & $\Delta \Delta / 9$ & 。 & $\%$ & 100 & ياليكورسكيت \\
\hline$\circ / \Lambda$ & $0 / r$ & $-0 / T$ & $\mathrm{~V} / \mathrm{A}$ & $T \mu / r$ & $Y Y / Y$ & $1 / T$ & $\%$ & 100 & كلريت \\
\hline
\end{tabular}

'كانى هاى منبسطشونده مجموع دو كانى اسمكتيت و ورمى كوليت هستند، KS: آزمون كولمو گروف - اسميرنوف

بررسى طيف وسيعى از تغييرات را نشان مىدهند. ميـانخين درصـد

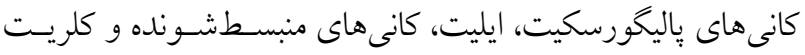

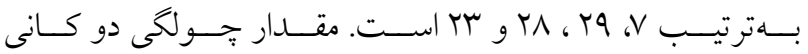
ياليخورسكيت و كانى هاى منبسطشونده مشت بـوده و نشـاندهنـده اين است كه مقدار كمتر اين دو كانى در خاكهاى سـطحى اسـتان فراوانى بيشتر دارند. اين درحاليسـت كـه توزيـع فراوانسى ايليـت و كلريت در خاكهاى استان نرمال بـوده و مقــدار جــولخى و آزمـون كولموكروف- اسميرنوف نيز مؤيد اين مطلب است.

نقشه يراكنش درصد رس خاكهاى سطحى استان اصفهان شكل ب نقشه ير اكنش درصد رس در خاكهاى سـطحى اسـتان اصفهان را نشان مىدهد. ميانخين درصد رس خاكهـاى اسـتان
شد مشاهده مىشود. بلدين معنـى كـه حسـداقل مقـدار دمـايى در مكانهايى با حداكثر بارش مشاهده مىشود و حداكثر دما نيز به مناطق شرقى و شمالى استان اختصاص دارد. توصيف آمارى ويزّگىهاى خاى و كانىهاى رسى جدول ا توصيف آمارى ويزگى هاى خاى در ه ما انمونه مـورد نظر را نشان مىدهد. ويزّى هاى خاى طيف وسيعى از تغييرات را دربرمى گيرند و از بين ويزخى هاى مورد بررسى ماده آلى، گج و شورى خاك جِولكى مثبت دارند بدين معنى كه مقـدار كمتــ اين ويزّكى ها فراوانى بيشتر دارند.

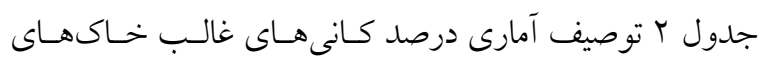
سطحى استان اصفهان را نشـان مسىدهـد. مقـدار كـانىهـاى مـورد 


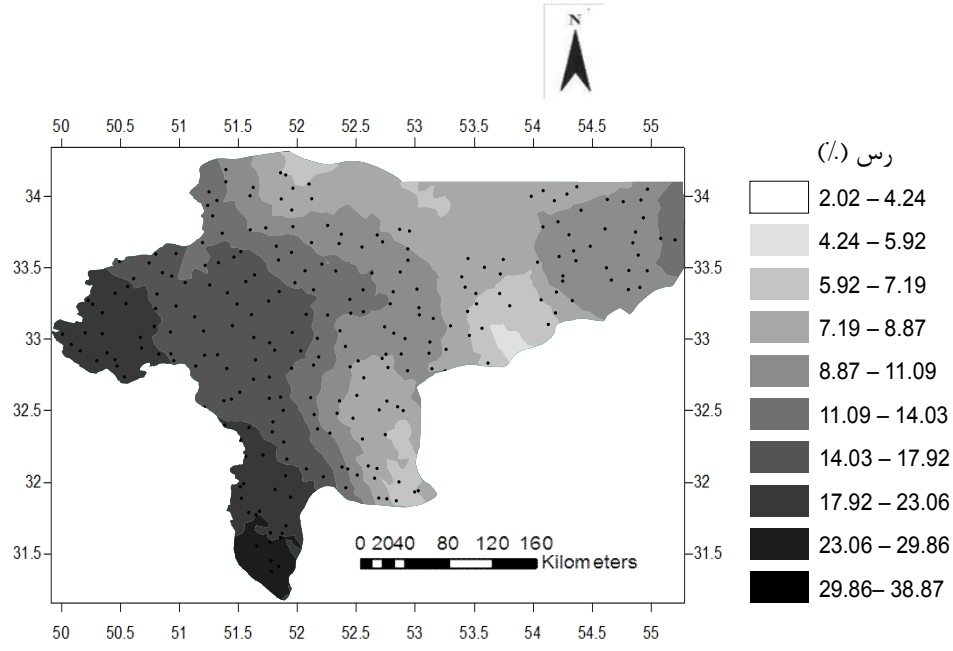

شكل f. تغيير ات مكانى درصد رس خاكهاى سطحى استان اصفهان

كـانىهـاى ورمسى كوليـت، ايليـت، كلريــت و كـوارتز در تمـامى خاكهاى استان حضور دارند و بسته به موقعيت جغرافيايى، اقليم و ماده مادرى كانى هاى باليخورسكيت و يا اسمكتيت نيز در خاك

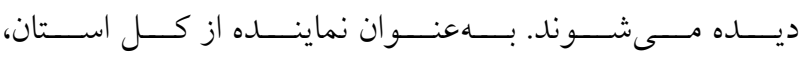
يراشنخاشتهاى برتو ايكس ؤنمونه خاك متعلق به سـه كـلاس اقليمى متفاوت در شكل ه نشان داده شده است. بهعـلاوه، مقـدار كانى هاى رسسى و خصوصسيات اقليمسى و فيزيكى و شسيميايى 9 نمونه خاى كفتهشده در جدولهاى ب و ب آملده است. منطقه مطالعاتى بر اساس شاخص اقليمى دومـارتن بـه سـه

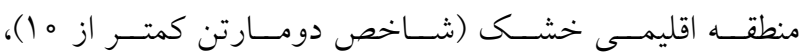

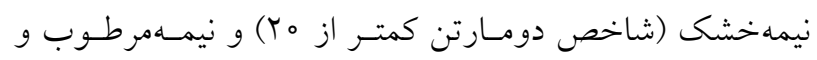
مديترانهاى (شاخص دومارتن كمتر از مب) كه بهطور كلى نيمسه مرطوب نام كرفت، تقسيم شد. بر اساس ايسن تقسـيمبنـدى ه

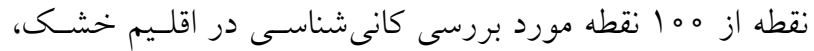
צץ نقطه در كلاس اقليمى نيمهذشك و 9 نقطه در كلاس نيمه مرطوب قرار دارند. بر ايسن اسـاس بـيش از م9 درصـد اسـتان داراى اقليم خشك و نيمه خشك است.

كانى شناسى بخش رس خاى در كلاس اقليمى خشى شكل ه- الف براشنخاشتهاى برتــو ايكـس دو نمونسه خـاك متعلق به كلاس اقليمى خشك را نشـان مسىدهـد. حضـور قلـه
1 T/9 درصد است و درصد رس در خاكهاى اسـتان بـين Y تـا هץ درصد متغير است و نمودار توزيع فراوانى درصد رس خاى در منطقه مطالعاتى نرمال است. بيشـترين مقـدار رس خـاك بـهـ مناطق غربى، شمال غربى و جنوب استان يعنسى شهرسـتانهـاى فريدن، جادكان، فريسدونشهر و سـميرم اختصـاص دارد. ايسن درحاليست كه كمترين ميـزان رس بـه منـاطق شـمال، شـرق و جنوب شرق مربوط است. با توجه به نقشه زمينشناسى منطقـه، در قسمتهاى شرقى و شمالى استان بيشتر سنخهــاى رسـوبى،

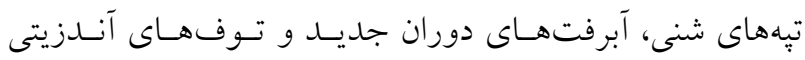
وجود دارد كه بافت خاك سطحى تشكيل شده روى ايسن مـواد مادرى حاوى شن و سيلت بيشـترى اسـت. در منـاطق غربسى و جنوبى استان مواد مادرى مارنى، سنخ آهك، شيل و سنخهـاى دكرگونى بيشتر ديلده مىشود؛ بنابراين، خـاك سـطحى تشـكيل

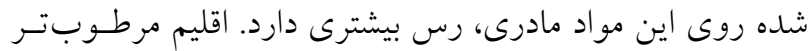
اين مناطق منجر به افزايش هواديدگى سنگها شده و علاوه بـر مواد مادرى اقليم منجـر بـهـ كـاهش درصـــ ذرات شـن در ايسن نواحى مىشود.

\section{شناسايى كانىهاى رسى خاك به روش XRD} مطالعات كيفى كانى شناسى رسى بر روى ه ما نمونه از خاكهاى

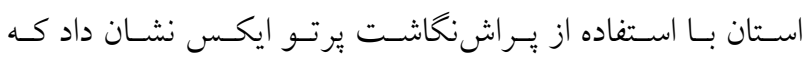


الف
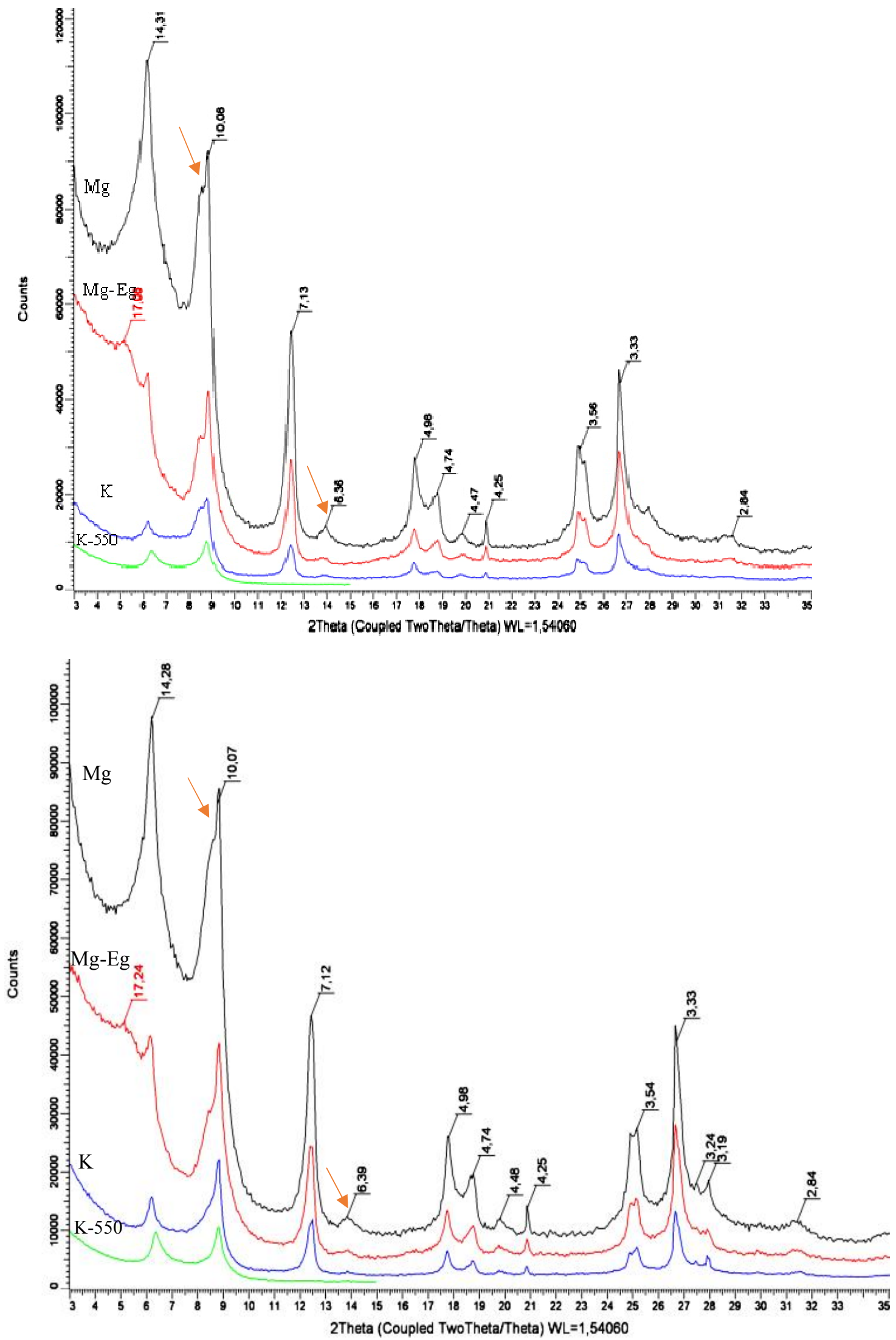

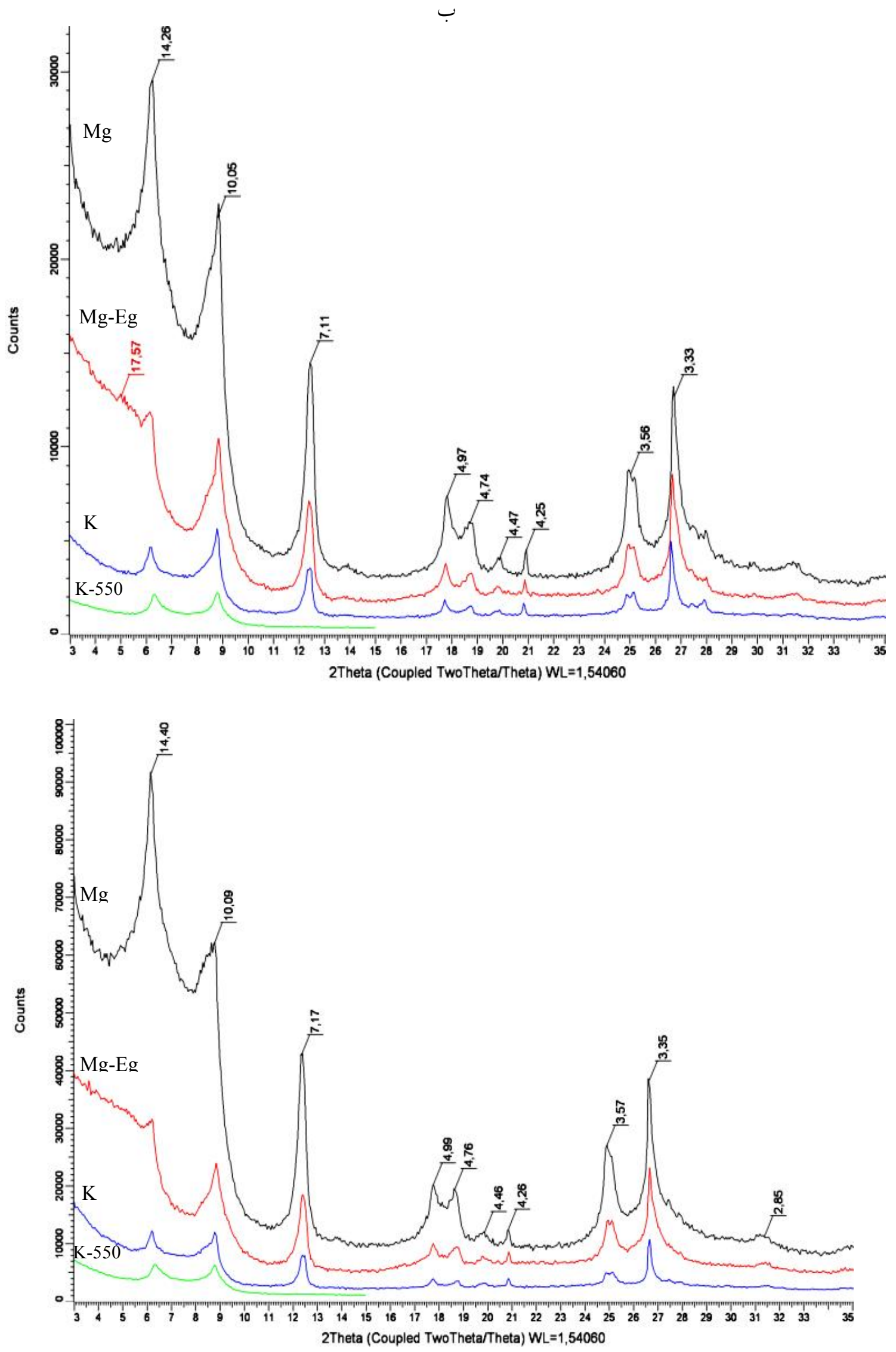

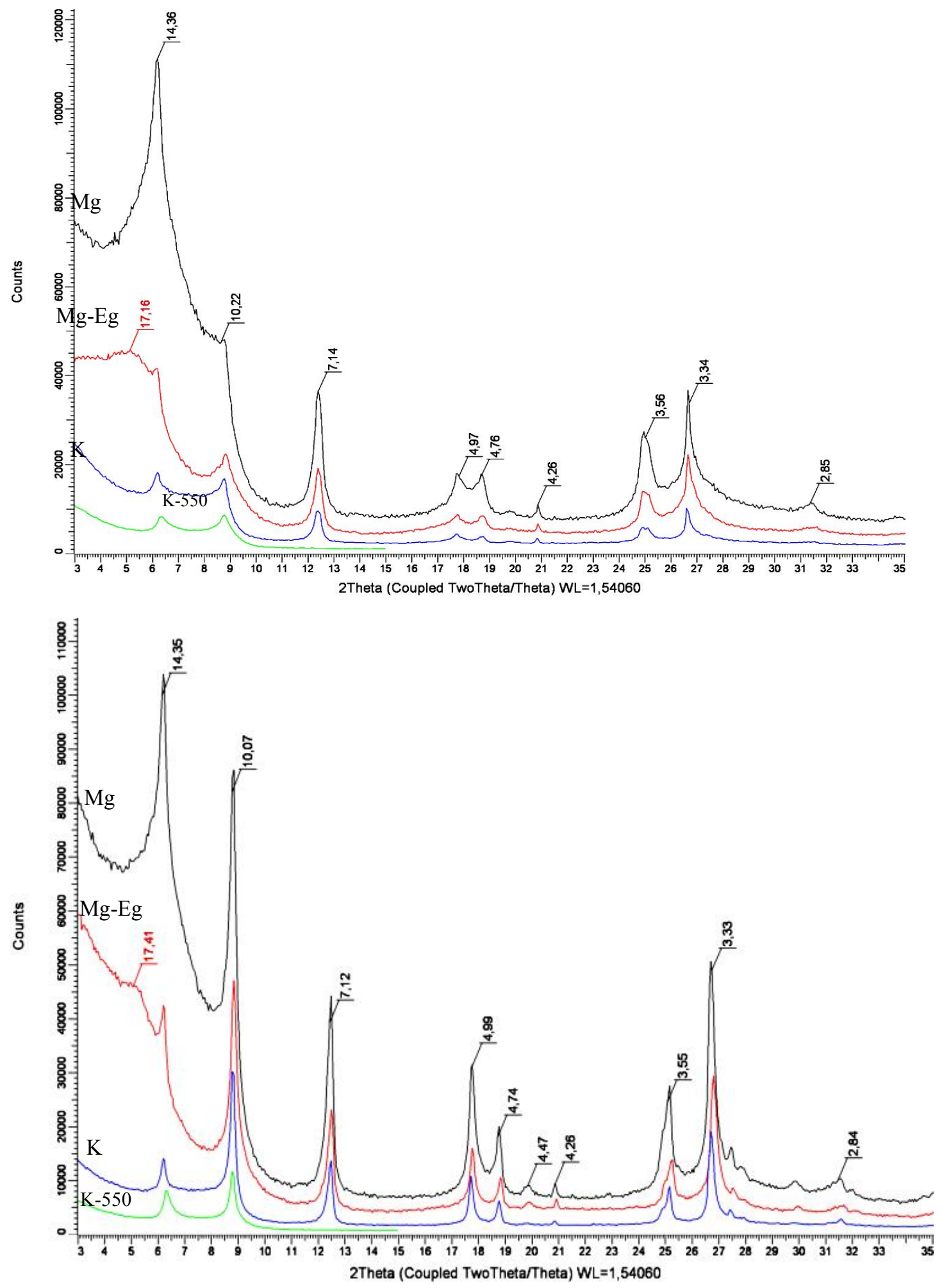

شكل ه. يراشنكاشتهاى يرتو ايكس نمونههاى خاك متعلق به كلاس اقليمى: الف) خشك، ب) نيمه خشك و ج) نيمهمرطوب

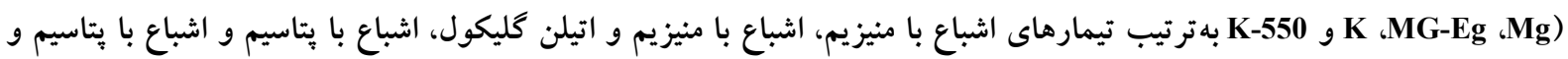

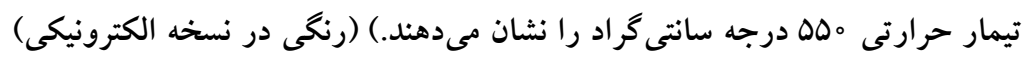


جدول r. مقدار كانىهاى رسى 9 نمونه خاى (درصد) در كلاسهاى مختلف اقليمى منطقه مطالعاتى

\begin{tabular}{|c|c|c|c|c|c|c|c|c|c|}
\hline كوارتز & بِاليكورسكيت & ايليت & كائولينيت & كلريت & منبسط هاى & كانى & مكان نمونه & كاربرى & كالس \\
\hline$V / D$ & $41 / r$ & $r M / \varphi$ & $0 / T$ & $14 / 9$ & $11 / 1$ & $0 / 99$ & (خور و بيابانك) & مرتع & \multirow{2}{*}{ خشك } \\
\hline $9 / 0$ & $\mu_{0 / 0}$ & $r N / 0$ & $\circ / \pi$ & $1 V / 9$ & $I V / T$ & $0 / r$ & (حسن آباد جرقوية) & مرتع & \\
\hline $10 / 1$ & $11 / 0$ & $\mu_{0} / \circ$ & $\circ / V$ & $Y Y / T^{K}$ & $r Y / \mu$ &.$/ 9$ & $\begin{array}{l}\text { نزديك مركز استان } \\
\text { (شهرضا، سولار) }\end{array}$ & مرتع & \multirow{2}{*}{ نيمه خشك } \\
\hline $\mid r / 4$ & $1 / 0$ & rl/。 & $\circ / \pi$ & ro/q & & $\circ / V$ & 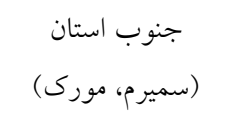 & مرتع & \\
\hline$I T / Y$ & $\circ / \Lambda$ & $1 \pi / 9$ & $\circ / 4$ & $r q / \mu$ & $M Y / r$ & $9 / 0$ & (ابتداى جاده سميرم-ونكى) & مرتع & \multirow{2}{*}{ نيمه مرطوب } \\
\hline $1 \pi / r$ & $\circ$ & $\Gamma_{\Lambda / \Delta}$ & $0 / 9$ & rE/I & $r \mid / l$ & $0 / \mu$ & 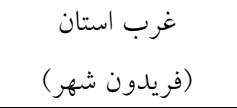 & مرتع & \\
\hline
\end{tabular}

'كانى هاى منبسطشونده: مجموع دو كانى ورمىكوليت و اسمكتيت هستند.

roo ميلى متر و ميانخين دماى سـالانه بـالا از خصوصسيات ايسن كلاس اقليمى است (جدول \&). ماده آلى كم و مقدار بالاى شن، سيلت، آهك و اغلب مقدار بالاى گج و شورى از خصوصسيات خاى در اين كالس اقليمى است.

كانى شناسى بخش رس خاك در كلاس اقليمى نيمه خشك شكل ه- ب براشنگاشت برتو ايكس دو نمونه خاى متعلق بـهـ كلاس اقليمى نيمه خشك در منطقه مطالعاتى را نشان مسىدهـد.

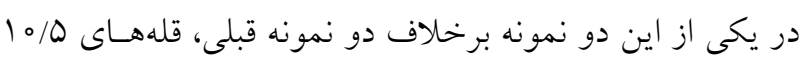
و $9 /$ آنخستروم بهطور ضعيف مشاهده مىشوند و بهوضوح دو

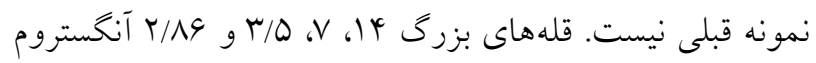
مقدار بالاى كانى كلريت در نمونسه خـاك مـورد نظـر را نشـان مىدهد. كانى ايليت در تمام خاكهاى استان وجود دارد ولى در خاكهاى منطقه مركزى استان بهطور غالب مشاهده مىشود. در نمونه خاك مورد نظر كـانىهـاى ايليـت، كلريـت و كـانىهـاى

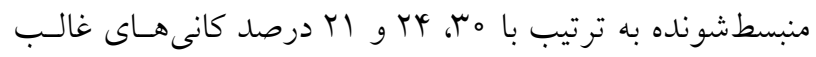

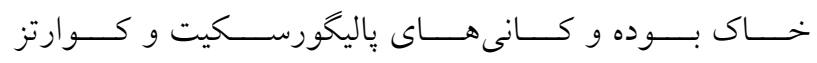

دوشاخ ه/ ا آنخستروم به همراه قلـه س/9 آنخستروم در تيمـار اشباع با منيزيم نشاندهنده حضور كانى ياليخورسكيت در هر دو

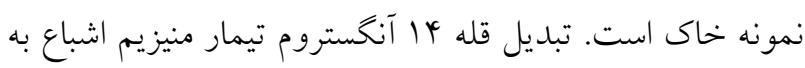
قله IV آنخستروم در تيمـار اشـباع بـا منيـزيم و اتسيلن كليكــول نشاندهنده حضور كانى هاى منبسـطــونده (مجمـوع دو كـانى ورمى كوليت و اسمكتيت) (تفكيك ورمسى كوليـت از اسـمكتيت نيازمند تيمار تكميلى كليسرول است. بـا توجـهـ بــه زيـاد بـودن نمونهها تفكيك ورمى كوليت از اسمكتيت صورت نخرفت و هر دو تحت عنوان كانىهاى منبسطشونده گزارش شدند) است. به

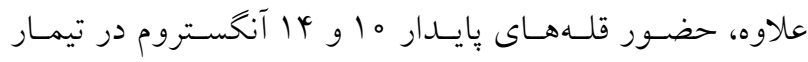

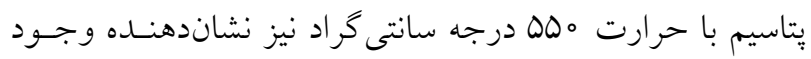
ايليت و كلريت در خاك مورد نظر است. كانى اوليه كوارتز (قله سر/ آنحستروم) نيز به مقدار كـم در خـاك مـورد نظـر وجــود

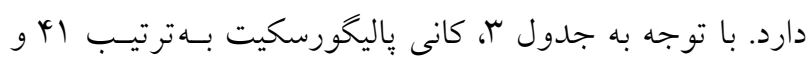
هr درصد از رس هر يك از خاكهاى مورد نظر را تشكيل داده و كانى غالب است، يس از آن ايليت و كلريت كانىهاى اصسلى

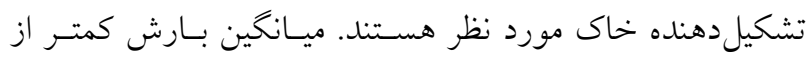


جدول أ. مقدار ويزّكى هاى اقليمى و خصوصيات فيزيكى و شيميايى \& نمونه خاك در كلاسهاى مختلف اقليمى

\begin{tabular}{|c|c|c|c|c|c|c|c|c|c|c|}
\hline \multirow{2}{*}{$\begin{array}{c}\mathrm{pH} \\
-\end{array}$} & \multirow{2}{*}{$\begin{array}{c}\mathrm{EC} \\
(\mathrm{dS} / \mathrm{m})\end{array}$} & سيلت & رس & شن & گَج & آهك & ماده آلى & \multirow{2}{*}{ ميانخين دماى ساليانه } & \multirow{2}{*}{ ميانخين بارش ساليانه } & \multirow{2}{*}{ كلاس } \\
\hline & & \multicolumn{6}{|c|}{$(\%)$} & & & \\
\hline $1 / 9$ & $r / v$ & $\varphi \circ / l$ & $\varphi / 0$ & $\Delta \Delta / \Lambda$ & $19 / 1$ & $r \circ / r$ & $\circ / 1$ & $r \circ / T$ & VG/A & \\
\hline$N / T$ & $0 / \mu$ & $14 / 9$ & $9 / 0$ & $V \wedge / Q$ & $T / D$ & $9 \mathrm{~V} / \mathrm{V}$ & $0 / T$ & $19 / \pi$ & $109 / 4$ & خشك \\
\hline$\Lambda / \circ$ & $0 / T$ & $r V / r$ & $19 / 9$ & $49 / 1$ & $\circ / \circ$ & $90 / r$ & $0 / 4$ & $1 \pi / 9$ & TYM/A & نيمه \\
\hline$V / q$ & $\circ / 1$ & $\mathrm{rq} / 9$ & $r Y / 0$ & $r y / 0$ & $\circ / \circ$ & TA/V & $1 / V$ & $\mid r / 4$ & $r r \circ / V$ & خشك \\
\hline$V / 9$ & $0 / r$ & $9 \wedge / \wedge$ & $\mid y / \Lambda$ & $19 / 4$ & $\circ \%$ & $1 V / D$ & $r / 4$ & $10 / 4$ & $\varphi \Delta q / \mu$ & نيمه \\
\hline $\mathrm{V} / \mathrm{\Lambda}$ & $0 / r$ & $Y y / D$ & $r q / r$ & $r q / 1$ & $\circ / 0$ & $4 \circ / 0$ & $T / Y$ & $9 / 9$ & $011 / 1$ & مرطوب \\
\hline
\end{tabular}

س/ (9/) مشاهده نمى شود. سه كـانى ايليـت، كلريست و كـانىهـاى منبسط شونده سه كانى اصلى تشكيل دهنـلده ايسن خـاك بـوده و كانى كوارتز نيز در اين خاكها مشاهده مىشود.

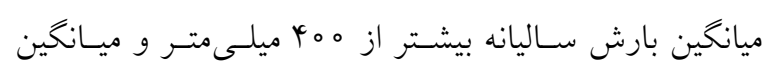
دماى سالانه يايين از خصوصسيات ايسن كـلاس اقليمسى اسـت.

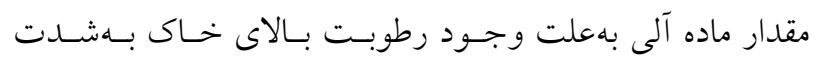

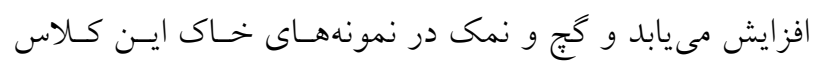
اقليمى مشاهده نمى شود (جدول ع) (ب).

نقشه يراكنث پياليخورسكيت در خاكهاى اســان اصسـفهان و ارتباط آن با اقليم و ماده مادرى

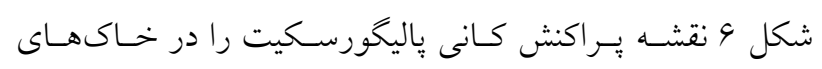

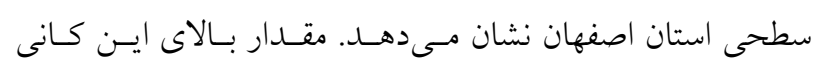
عموماً در شرق، شمال و جنوب شرق استان مشـاهده مسىشـود. با توجه به نقشه يراكنش دما و بارش اسـتان اصـفهان (شـكل م

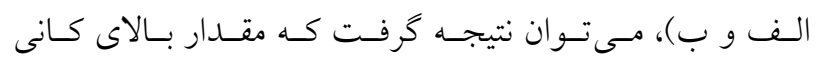
ياليخورسـكيت بيشـتر در منـاطق خشـك اسـتان بــا دمـاى بــالا

$$
\text { مشاهده مىشود. }
$$

در منــاطق غربـى، جنـوب غربـى و جنــوبى اسـتان كـهـ

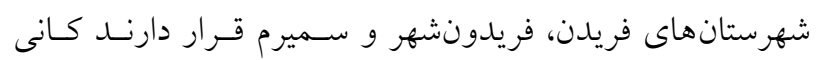
ياليكورسكيت در خاك وجود ندارد. نقشه زمسينشناسـى اسـتان
با 11 و ه ا درصد بخش باقىمانده اين خاك را تشكيل مىدهند

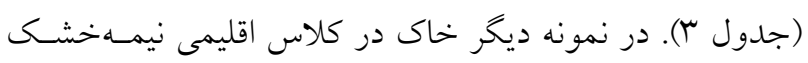
در شكل ه- ب، بر خلاف نمونههاى قبلى هيج قلهاى مرتبط بـا

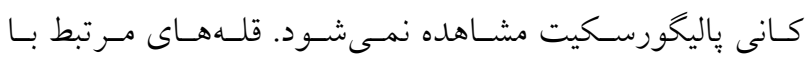

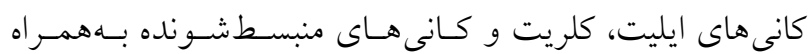
كوارتز در اين خاك مشاهده مىشود. بهنظر مىرسد، با افـزايش رطوبت كانى پاليخورسكيت به كانى هاى منبسطشونده از جملـه

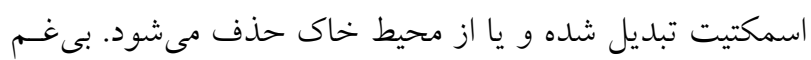
و همكاران (Y) معتقدند كه باليخورسكيت و اسمكتيت در خاك اغلب با يكديخر حضور دارند و كاهش پِاليكورسكيت در خاى را با افزايش اسمكتيت هماهنخ دانستهاند. ميانخين بارش سالانه

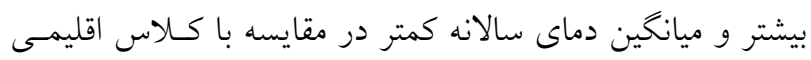

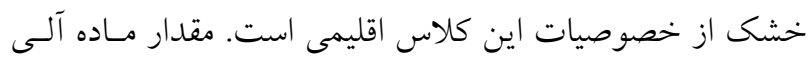
خاك در مقايسه با كلاس اقليمى خشك افزايش يافتـه و مقـدار كج و شورى در خاكهاى اين كلاس اقليمى بسيار اندك اسـت

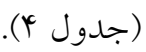

كانى شناسى بخش رس خاى در كلاس اقليمى نيمهرطوب يراشنخاشت يرتو ايكس دو نمونه خاك متعلق به كلاس اقليمى نيمهمرطوب منطقه مطالعـاتى در شـكل ه- ج نشـان داده شــه است. هيج قلهاى مرتبط با كانى ياليخورسكيت (قلههاى 10/ ا و 


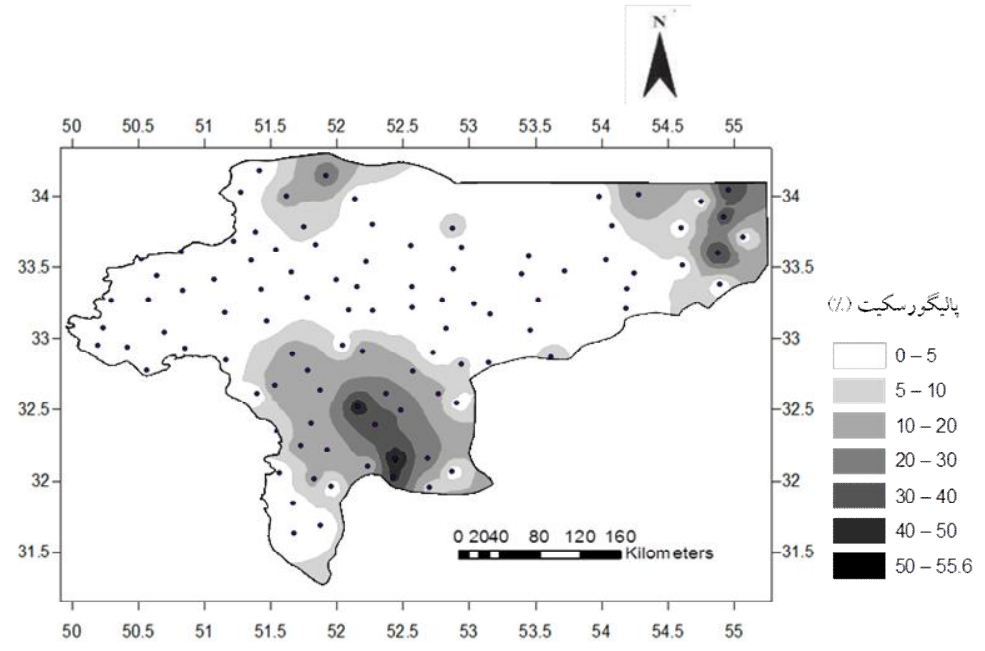

شكل 9. تغييرات مكانى درصد بِاليخورسكيت خاكهاى سطحى استان اصفهان

در منطقه اصفهان را مورد بررسى قرار داده و دريافتند كه علاوه بر به ارث رسيدن از ماده مادرى، ياليخورسكيت مىتواند بهطور

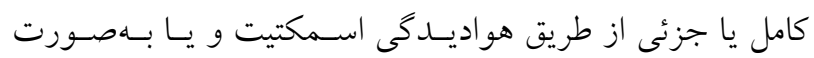

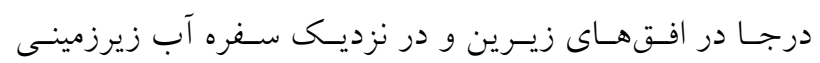
تشكيل شود. تشكيل پياليكورسكيت در خاكهاى مناطق خشكى ريك

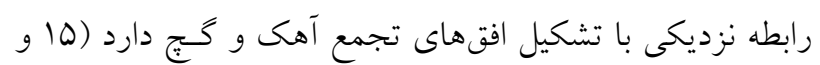

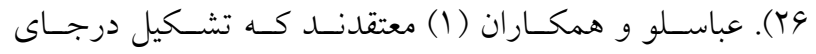
ياليخورسكيت در دوران ترشيارى و در حوضجههاى كمعمق به علت شرايط محيطى قليايى (حضور گجّ و آهك) مهمتـرين دليـل حضور باليخورسكيت در سنخهاى رسوبى و خاكهـاى تشـكيل شده از آنهاست. اوليـايى و همكـاران (YO) نيـز معتقدنــ كـهـ راه اصلى ورود ياليكورسكيت در منطقه مـورد مطالعـه آنهـا تشكيل درجاى اين كانى در اثر رسوب گج و آهك است و تبـديل سـاير كانىها به ياليخورسكيت و به ارث رسيدن از ماده مادرى بهعنـوان منابع بعدى ورود اين كانى به خاى معرفى شدند.

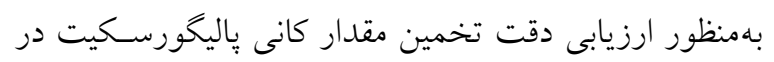

روش وزندهى معكـوس فاصـله، از دو يــارامتر ميـانكين خطـا و جذر ميـانخين مربعـات خطـا (RMSE) (جدول ه). ميانخين خطا، مقدار اريبى را نشان مسىدهـد كـه در حالت مطلوب بايد مساوى صفر باشد. مقدار مثبت و منفى زياد

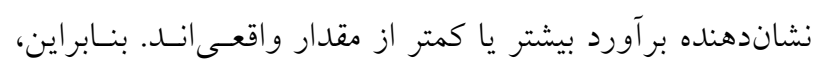

اصفهان (شكل r) نيز نشان مىدهــ كـه عمـده رسـوبات قرمـز بالايى، قرمز تحتانى و قـم كـه مربـوط بـهـ دوران زمسينشناسىى ميوسن و ويليوسن هستند در مناطق شرقى و شمالى اسـتان قـرار دارند و حاوى مقدار قابل توجهى كانى يُاليكورسـيت هسـتند.

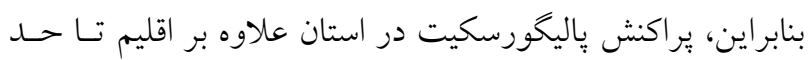
زيادى به نوع ماده مادرى خاك ارتباط دارد. بهنظر مىرسد مـاده مادرى در ورود اين كانى به محيط خاى و اقليم بـهــور عمــده در بايدارى و حفظ اين كانى و تا حسدى تشـكيل محسدود ايسن كانى در خاكهاى استان مؤثر بوده است. نتايج بررسىهاى انجام شده، سه فرضيه براى توجيه وجـود ياليكورسكيت در خاك را به اثبات رسـانده اسـت: ا- بـهـ ارث رسـيدن از مــاده مــادرى، خــادمى و مرمــوت (سب) وجـــود ياليكورسكيت در مواد مادرى ايران مركزى را به بالا آمدن فلات ايران و جدا شدن دريـاى تتسيس از اقيـانوس اصـلى در اواخــر كرتاسه و تشكيل درياجههاى كمعمق و شـور و مناسـب بـراى تشكيل رسهاى فيبرى نسـبت مسىدهنــ. Y- خاسـتخاه آوارى،

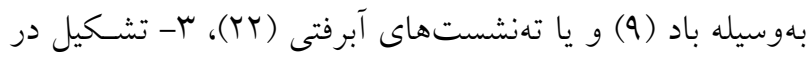

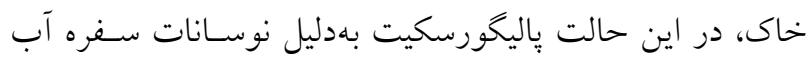
زيرزمينى، در اثر تغيير شكل اسمكتيت و يا تشـكيل در محلـول

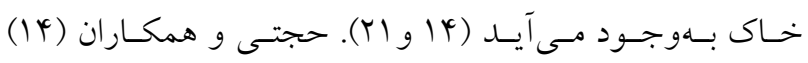
تشكيل ياليخورسكيت تحت تأثير آب زيرزمينى شـور و قليـايى 
جدول ه. ارزيابى خطاى تخمين روش وزندهى معكوس فاصله كانىهاى رسى غالب بهروش اعتبارسنجى متقاطع

\begin{tabular}{|c|c|c|}
\hline RMSE & $\mathrm{ME}$ & نوع كانى \\
\hline $10 / 1$ & $0 / 41$ & ياليخو رسكيت \\
\hline $9 / 9$ & $-0 / 0 Y$ & ايليت \\
\hline $11 / 1 r$ & $4 / 04$ & كانى هاى منبسطشونده \\
\hline$V / 9$ & $r / 1$ & كلريت \\
\hline
\end{tabular}

جدول 9. همبستخى ويزّى هاى خاى با مقدار نيمه كمّى كانىهاى مورد مطالعه

\begin{tabular}{|c|c|c|c|c|c|c|c|c|}
\hline $\mathrm{pH}$ & $\mathrm{EC}$ & 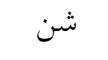 & سيلت & 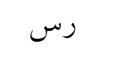 & كَّ & آهك & ماده آلى & نوع كانى \\
\hline$-0 / 09$ & $-0 / 1$ & $-0 / 0 \psi^{4}$ & 0109 & $-0 / 09$ & $\% \circ \mathrm{V}$ & $-0 /\left.4\right|^{* *}$ & $\%$ & كانى هاى منبسطشونده \\
\hline$-0 / 0 Y$ & $\circ / 1 r$ & $-0 / 0 \mu$ & $-\circ / \circ \mu$ & $-0 / 19$ & $\circ / 1$ & $0 / 01$ & $-0 / 0 \mu$ & ايليت \\
\hline $0 / 1$ & $\circ / I V$ & $\circ / Y \omega^{*}$ & $-0 / Y I^{*}$ & $-0 / T r^{*}$ & $\circ / \mu_{\circ}^{* *}$ & $\circ / \uparrow \wedge^{* *}$ & $-o / Y^{* *}$ & يِاليخورسكيت \\
\hline$\circ / 1$ & $0 / 19$ & $-0 / 04$ & $-0 / 09$ & $\circ / r$ & $-\circ / \mu^{* *}$ & $-0 / 14$ &.$/ 14$ & كلريت \\
\hline
\end{tabular}

هر جهه اين مقدار كمتر ياشند نشاندهنده خطـاى كمتـر تخمسين ياليخورسكيت فراهم مىشود. است. مقدار ME و RMSE براى تخمين كانى ياليخورسكيت در

نقشه يراكنش ايليت در خاكهاى استان اصفهان و ارتباط آن روش وزندهى معكوس فاصله بهترتيب ع/ و 1/ إست. با اقليم و ماده مادرى

برخلاف نقشه ير اكنش كانى پِاليكورسكيت، يــراكنش ايليـت در

همبستخى مقدار كانى ياليخورسكيت با ويزگگىهاى خاى

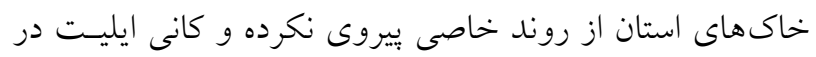
جدول و ضرايب همبستخى اسـيرمن ويزگكى هـاى خـاك و تمامى مناطق استان مشاهده مىشود (شكل V). البته لازم به ذكر

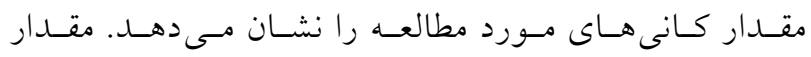
است كه مقدار بالاى اين كانى بيشتر در منـاطق مركـزى اسـتان

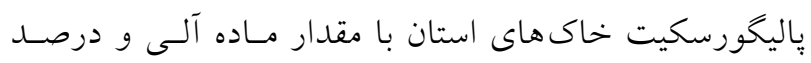
مشاهده مىشود. كانى ايليت و بهطور كلى كـانىهـاى ميكـايى

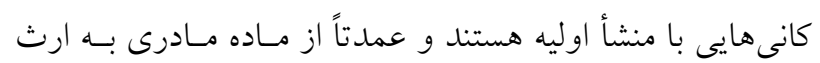
رس و سيلت خاكهاى استان همبسـتحى منفى و معنى دار نشان مى دهد. درحالى كه همبستخى مقدار باليخورسكيت بـا مىرسند. تشكيل و توزيع اين كانى تابع اقليم نبوده و وابسته بـهـ درصد آهك و گَج مثبت و معنسى دار اسـت. در منساطقى كـه ماده مادرى است. ايليت در خاكهــاى جـوان و كمتـر هواديــه

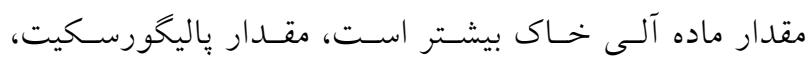
فراوان و در خاكهاى هو اديلده بهمراتب كمتـر ديــده مسىشـوند درصد آهك و گَج خـاك كمتـر اسـت. ايسن مسـئله بـهـور

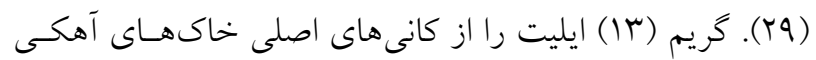
غيرمستقيم بـه اقليم منطقه ارتبـاط دارد. در منـاطق بـا اقلـيم

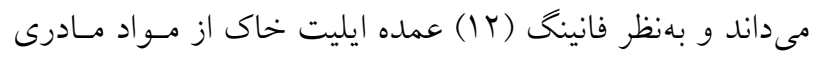
خشك، بارش باران براى شستشوى املاح محلـول و گـــ از رسوبى ايجاد مىشود. خاى كافى نبوده و مقدار زيـادى از امـلاح و گَجـ در خــاك تجمع يافته و شـرايط بـراى توليــ كـانى هــاى فيبـرى نظيـر 


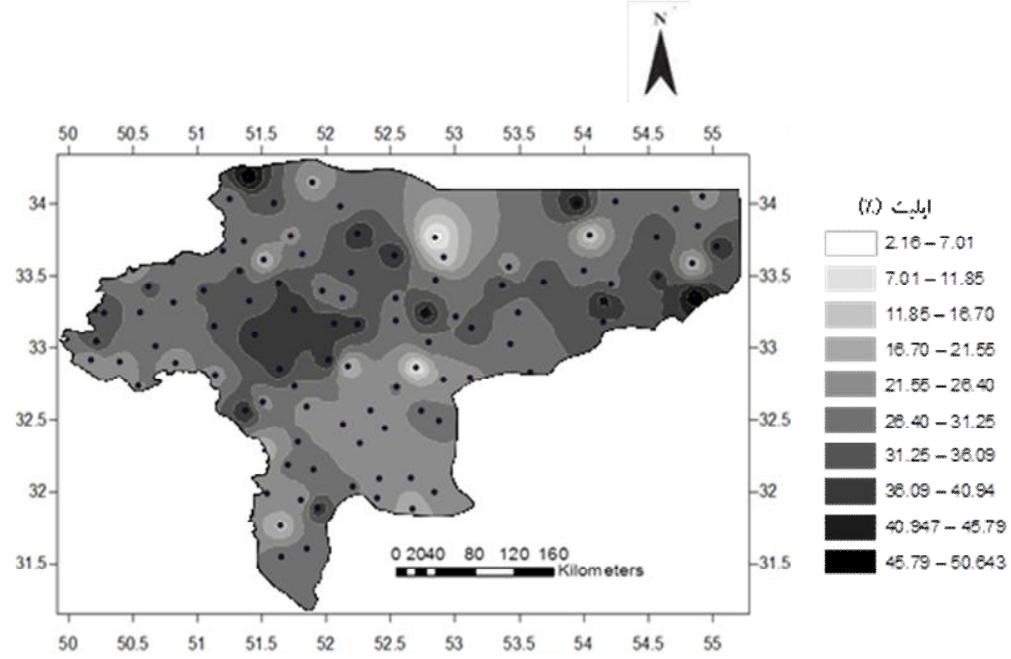

شكل V. تغييرات مكانى درصد ايليت خاكهاى سطحى استان اصفهان

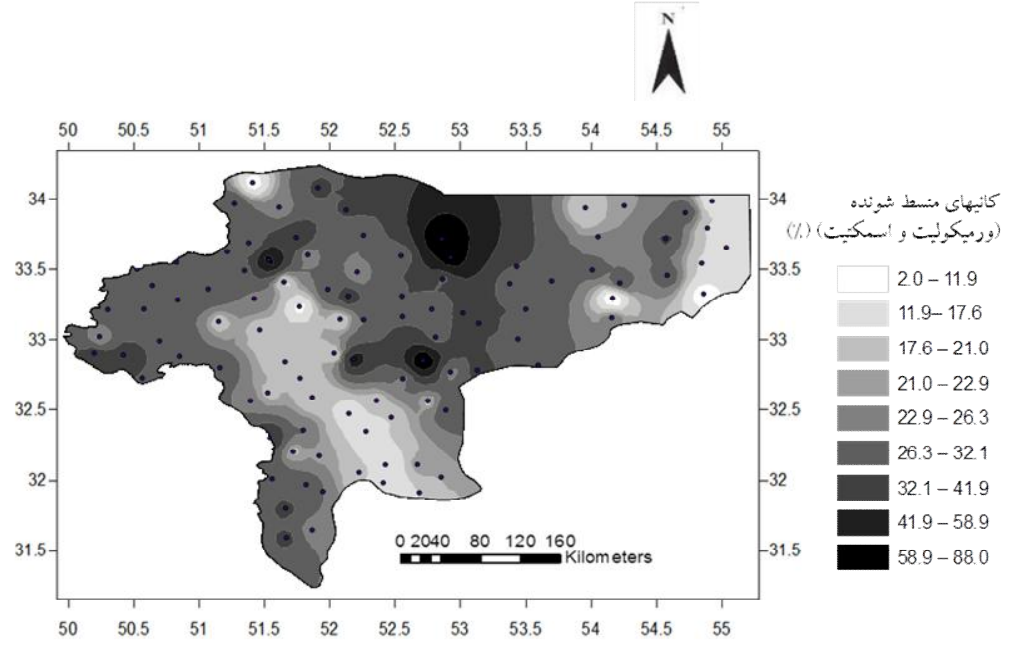

شكل ^ ـ تغييرات مكانى درصد كانىهاى منبسطشونده خاكهاى سطحى استان اصفهان

اسمكتيت) خاكهاى سطحى استان اصفهان در شكل 1 آمده

است. بهجز در مناطق شرقى، مركزى و جنوبشــقى اسـتان كه مقدار كم كانى هاى منبسط شـونده مشـاهده مسىشـود، در ساير مناطق استان مقدار اين كانىهـا بـالا اسـت. بـالا بـودن

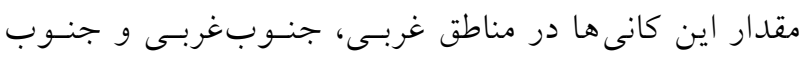

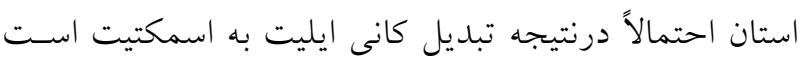

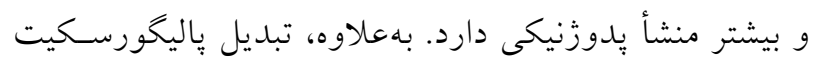
به اسمكتيت منشأ ديخر حضور اين كانى در خاى است (Y). اقليم مرطوبتر مناطق كفتـهــــه شـرايط را بـراى تغييـر و تحول كانى ها فراهم مى كند (شكل r- الف). درحالى كـه در
همبستخى مقدار كانى ايليت با ويز گیىهاى خاى همبستخى مقدار كانى ايليت با ويز گى هاى خاى معنسى دار نبـود (جدول 9). با توجه به اينكـهـ اغلـب خصوصسيات خـاك مـورد بررسى در استان تحت تأثير اقليم است ولى مقــار ايليـت تـابع

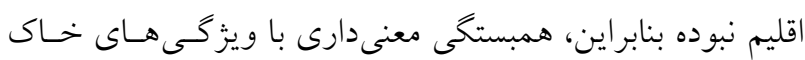

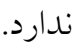
نقشه يراكنش كانى هاى منبسط شونده در خــاكهـاى اسـتان اصفهان و ارتباط آن با اقليم و ماده مادرى نقشه بر اكنش كانى هاى منبسطشونده (مجموع ورمىكوليت و 


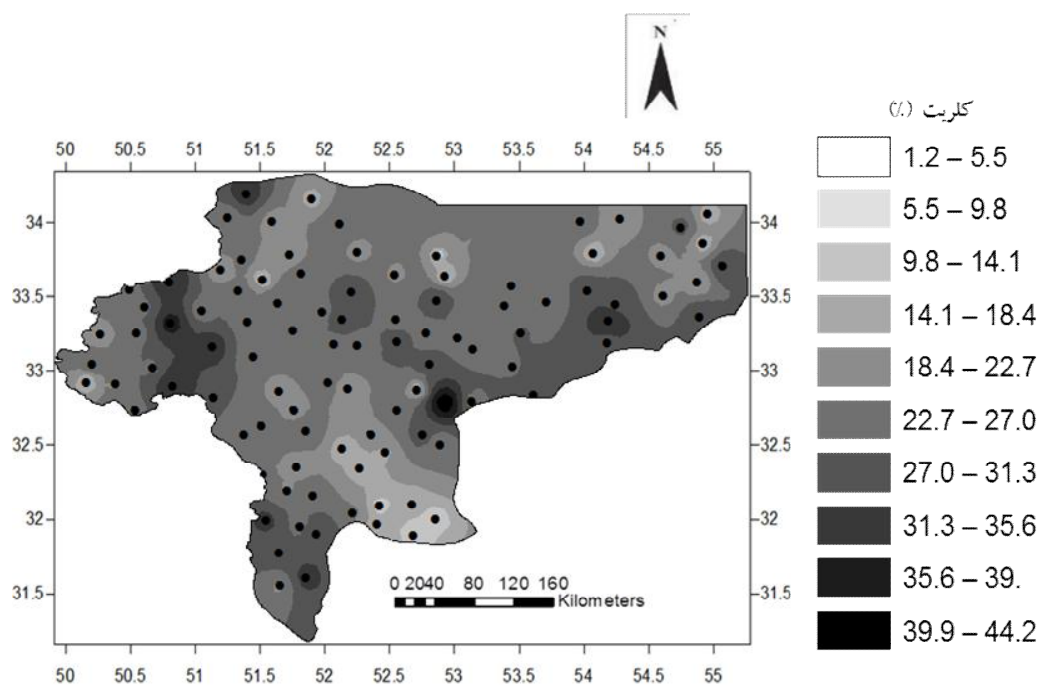

شكل 9. تغييرات مكانى درصد كلريت خاكهاى سطحى استان اصفهان

نقشه ير اكنش كلريت در خاكهاى استان اصـفهان و ارتبـاط

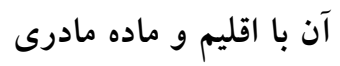
ير اكنش كلريت در خاكهاى استان اصفههان در شـكل 9 نشـان

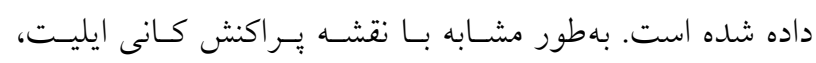

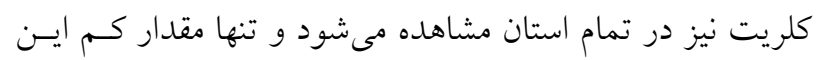

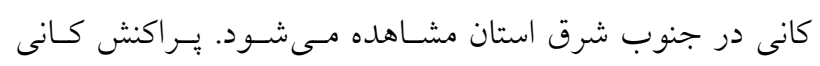
كلريت نيز مانند ايليت تابع اقليم نبوده و وابسته به مـاده مـادرى

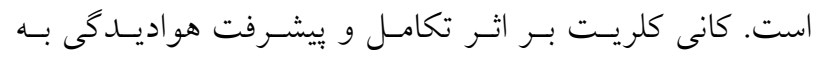

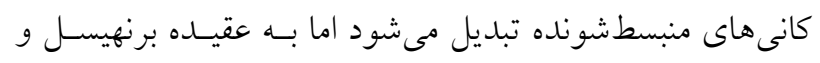

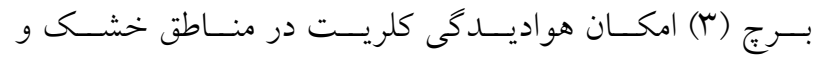

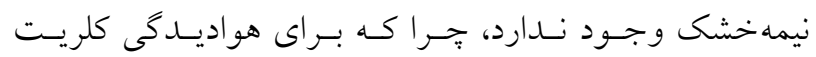

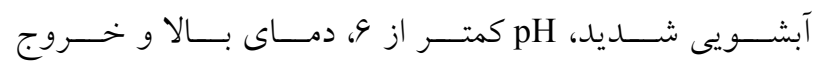

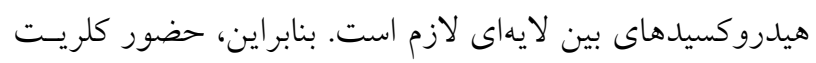

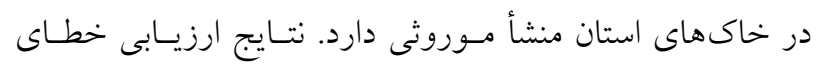

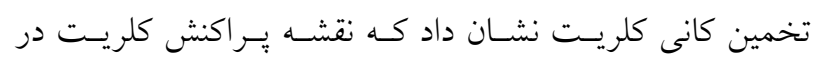

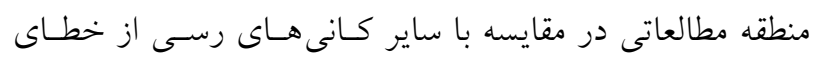

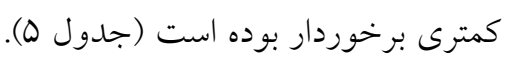

همبستگى مقدار كانى كلريت با ويزّكىهاى خاك

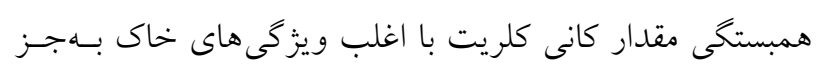

منــاطق شــمالى و شــمالشـرقى كـهـ روى نــوار آتشفشـانى

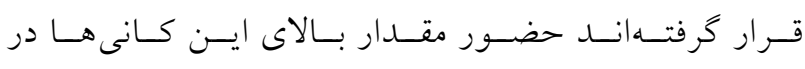

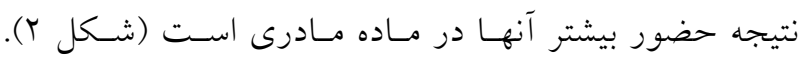

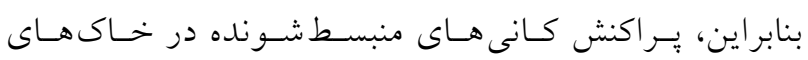
سطحى استان اصفهان متأثر از دو عامل اقليم و مـاده مـادرى منئي

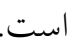

همبستخى مقدار كانىهاى منبسطشونده با ويزگىهاى خاى

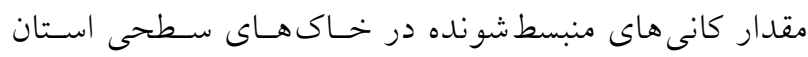
اصفهان تنها با مقدار آهك همبستكى منفى و معنى دار نشـان منسان

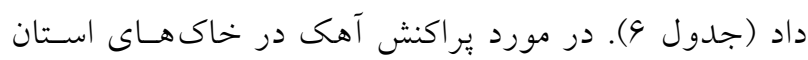

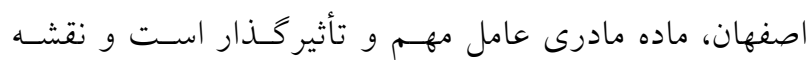

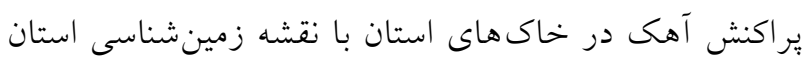

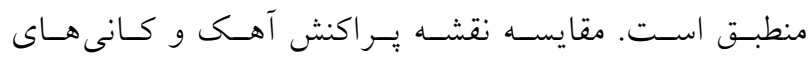

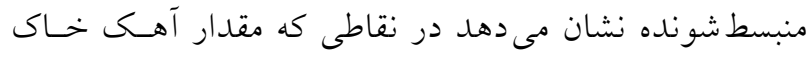

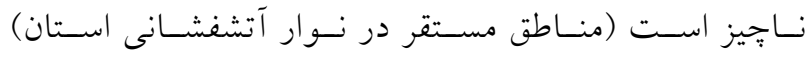

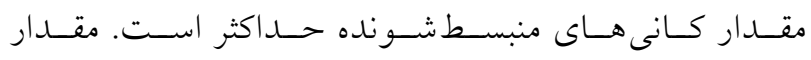

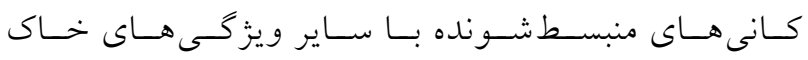
نظير شورى، مقدار گج، بافت خاى و مقدار ماده آلى ارتباط معنى دارى نداشت (جدول 9). 


$$
\begin{aligned}
& \text { يراكنش كانى باليخورسكيت، بر اكنش دو كانى ايليـت و كلريـت }
\end{aligned}
$$

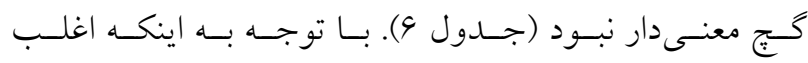

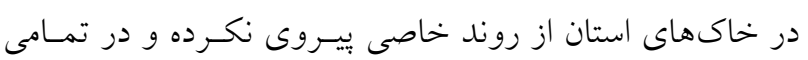

$$
\begin{aligned}
& \text { خصوصيات خاك مورد بررسى در استان تحت تأثير اقليم است } \\
& \text { مناطق استان مشاهده مىشود. يراكنش اين دو كانى تحــت تـأثير }
\end{aligned}
$$

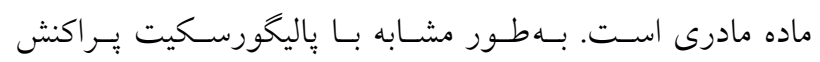

$$
\begin{aligned}
& \text { ولى مقدار كلريت تابع اقليم نبوده بنابراين، همبستخى معنىدارى } \\
& \text { با ويز كى هاى خاى ندارد. } \\
& \text { كانىهاى منبسطشونده در خاكهاى سطحى استان اصـفهان نيـز } \\
& \text { متأثر از دو عامل اقلـيم و مـاده مـادرى اسـت. در منـاطق نيمــه } \\
& \text { مرطوب غرب و جنوب غـرب اسـتان نقـش اقلـيم در بــر اكنش } \\
& \text { كانى هاى منبسـطــونده از اهميـت بيشـترى برخـوردار اسـت. } \\
& \text { درحالى كه در مناطق خشك و نيمهخشك شرق استان، اهميـت } \\
& \text { ماده مادرى بيشتر است. } \\
& \text { سياسگزן ارى } \\
& \text { نمونهبردارى و برخحى آناليزهاى آزمايشـاهـى بـا حمايـت مـالى } \\
& \text { دانشخاه صنعتى اصفهان انجام شده است كه بدينوسيله قـدردانى } \\
& \text { مىشود. بهعـلاوه، از دانشـحاه يُسى تكنيـك كارتاخنـاى اسـيانيا } \\
& \text { بهمنظور همكارى در انجام آناليزهاى XRD قدردانى مىشود. } \\
& \text { نتايج مربوط به تهيه نقشه كـانى هـاى رسىى غالـب خـاكهـاى } \\
& \text { ســطى اسـتان اصـفهان نشـان داد كــهـ مقــدار بــالاى كـانى } \\
& \text { ياليخورسـكيت بيشـتر در منـاطق خشـى اسـتان بـا دمـاى بـالا } \\
& \text { مشاهده مىشود. در مناطق غربى، جنوب غربى و جنوبى استان، }
\end{aligned}
$$

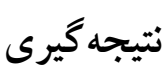

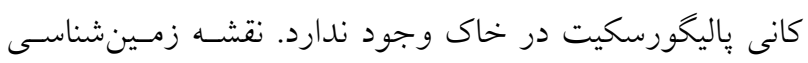

$$
\begin{aligned}
& \text { استان نيز نشان مى دهد كه عمده رسـوبات قرمـز بـالايى، قرمـز } \\
& \text { تحتانى و قم كه مربوط به دوران زمينشناسى ميوسن و يليوسن } \\
& \text { هستند در مناطق شرقى و شـمالى اسـتان قـرار دارنــــ و حساوى } \\
& \text { مقادير قابل توجهى كانى ياليكورسكيت هستند. بنابراين، بهنظـ } \\
& \text { مىرسد ماده مادرى در ورود اين كانى به محسيط خــاك و اقلـيم }
\end{aligned}
$$

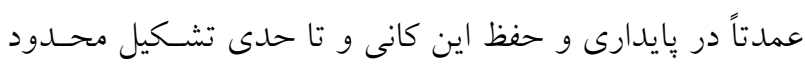

$$
\begin{aligned}
& \text { اين كانى در خاكهاى استان مؤثر بــوده اسـت. بـرخلاف نقشـهـ }
\end{aligned}
$$

\section{منابع مورد استفاده}

1. Abbaslou, H., A. Abtahi, F. J. M. Peinado, H. R. Owliaie and F. Khormali. 2013. Mineralogy and characteristics of soils developed on Persian Gulf and Oman sea basin, southern Iran: Implications for soil evolution in relation to sedimentary parent material. Soil Science: An Interdisciplinary Approach to Soil Research 178: 568-584.

2. Asakereh, H. 2008. Kriging application in climatic element interpolation A Case Study: Iran Precipitation in 1996.12.16. Geography and Development 12: 25-42. (In Farsi).

3. Barnhisel, R. I. and P. M. Bertsch. 1988. Chlorite and hydroxy interlayer vermiculite and smectite. PP: 729-788. In: Dixon, J. B. and S. B. Weed, (Eds.), Minerals in Soil Environment. SSSA. Book series. Madison. WI., USA.

4. Bigham J., W. Jaynes and B. Allen. 1980. Pedogenic degradation of sepiolite and palygorskite on the Texas High Plains. Soil Science Society of America Journal 44: 159-167.

5. Booth, B. 2000. Using ArcGIS 3d Analyst. GIS by Esri, Copyright, Environmental Systems Research. ESRI Press. USA.

6. Brindley, G. W. 1980. Quantitative X-ray mineral analysis of clays. PP. 411- 438. In: Brindley, G.W. and G. Brown, (Eds.), Crystal Structures of Clay Minerals and their X-ray Identification. Mineral. Soc., London.

7. Chipera, S. J. and D. L. Bish. 1995. Multi-reflection RIR and intensity normalizations for quantitative analyses: Applications to feldspars and zeolites. Powder Diffraction 10: 47-55.

8. Churchman, G. J., P. G. Slade, P. G. Self and L. J. Janik. 1994. Nature of interstratified kaolin-smectites in some Australian soils. Australian Journal of Soil Research 32: 805-822.

9. Coudé-Gaussen, C. 1987. Observation au MEB de fibres de palygorskite transportée en grains par le vent. PP: 199205. In: Federoff, N., L. M. Bresson and M. A. Courty, (Eds.), Micromorphologie des Sols. Association Française pour 1' Étude du Sol, Paris. 
10. Egli, M. 2013. Quantifying mineral abundances of complex mixtures by coupling spectral deconvolution of SWIR spectra (2.1-2.4 $\mu \mathrm{m})$ and regression tree analysis. Geoderma 207: 279-290.

11. Egli, M., M. Nater, A. Mirabella, S. Raimondi, M. Plötze and L. Alioth. 2008. Clay minerals, oxyhydroxide formation, element leaching and humus development in volcanic soils. Geoderma 143: 101-114.

12. Fanning, D. S. 1989. Soil Morphology, Genesis and Classification. John Wiley and Sons, New York.

13. Grim, R. E. 1963. Applied Clay Mineralogy. International Series in the Earth Sciences, McGraw-Hill Book Company, New York.

14. Hojati, S., H. Khademi and A. F. Cano. 2010. Palygorskite formation under the influence of saline and alkaline ground-water in central Iranian soils. Soil Science 175: 303-312

15. Hojati, S., H. Khademi, A. Faz Cano, S. Ayoubi and A. Landi. 2013. Factors affecting the occurrence of palygorskite in central Iranian soils developed on Tertiary sediments. Pedosphere 23: 359-371.

16. http://www.ngdir.ir

17. http://www2.ostan-es.ir/Default.aspx?tabid=303

18. Irmak, A., P. K. Ranade, D. Marx, S. Irmak, K. G. Hubbard, G. E. Meyer and D. L. Martin. 2010. Spatial interpolation of climate variables in Nebraska. Transactions of the ASABE (American Society of Agricultural and Biological Engineers) 53: 1759-177.

19. Jackson, M. L. 1979. Soil Chemical Analysis Advanced Course. $2^{\text {nd }}$ Edition. University of Wisconsin, Madison, WI.

20. Johns, W. D., R. E. Grim and W. F. Bradley. 1954. Quantitative estimation of clay minerals by diffraction methods. Journal of Sedimentary Petrology 24: 242-251.

21. Karimi, A., H. Khademi and A. Jalalian. 2009. Genesis and distribution of palygorskite and associated clay minerals insoils and sediments of southern Mashhad. Iranian Journal of Crystallography and Mineralogy 16: $545-558$ (In Farsi).

22. Khademi, H. and A. R. Mermut. 1998. Source of palygorskite in gypsiferous Aridisoils and associated sediments from Iran. Clay Minerals 33: 561-578.

23. Khademi, H. and A. R. Mermut. 1999. Submicroscopy and stable isotope geochemistry of carbonate and associated palygorskite in Iranian Aridisoils. European Journal of Soil Science 50: 207-216.

24. Mulder, V. L., S. de Bruin, J. Weyermann, R. F. Kokaly and M. E. Schaepman. 2013. Characterizing regional soil mineral composition using spectroscopy and geostatistics. Remote Sensing of Environment 139: 415-429.

25. Owliaie, H. R., A. Abtahi and R. J. Heck. 2006. Pedogenesis and clay mineralogical investigation of soils formed on gypsiferous and calcareous materials, on a transect, Southwestern Iran. Geoderma 134: 62-81.

26. Shahrokh, V. and H. Khademi. 2018. Factors influencing the formation and distribution of Palygorskite in Tertiary sediments and their soils around Darab City of Fars Province. Iranian Journal of Crystallography and Mineralogy 26: 423-436. (In Farsi).

27. Singh, B. and R. J. Gilkes. 1992. Properties of soil kaolinites from southwestern Australia. Journal of Soil Science 43: 645-667.

28. Smith, K. A. 1991. Soil Analysis. 2nd ed., Marcel Decker, New York.

29. Sparks, D. L. 1987. Potassium dynamics in soils. Advances in Soil Science 6: 1-63.

30. Vicente, L. E. and C. R. de Souza Filho. 2011. Identification of mineral components in tropical soils using reflectance spectroscopy and advanced space borne thermal emission and reflection radiometer (ASTER) data. Remote Sensing of Environment 115: 1824-1836.

31. Viscarra Rossel, R. A. 2011. Fine-resolution multiscale mapping of clay minerals in Australian soils measured with near infrared spectra. Journal of Geophysical Research 116: 1-15.

32. Wilson, M. J. 1987. A Handbook of Determinative Methods in Clay Mineralogy. Blackie and Son, New York. 


\title{
Mapping the Dominant Clay Minerals in the Soils of Isfahan Province and Their Relationship with Climate and Parent Materials
}

\author{
F. Khayamim*, H. Khademi and S. Ayoubi ${ }^{1}$
}

\begin{abstract}
Understanding the abundance of clay minerals in soil and also, their spatial variability can provide more comprehensive information about soil properties, behavior and functions. The objectives of this research were: (i) to map the spatial distribution of the dominant clay minerals in the soils of Isfahan Province and its relationship with climate and parent materials, and (ii) to determine the quantity of the dominant clay minerals in different climatic classes of Isfahan Province. The amount of palygorskite, illite, expanded minerals and chlorite were semi-quantitatively determined for 100 soil samples collected from Isfahan Province. Maps of the dominant clay minerals were prepared by the Inverse Distance Weighting method. The results showed that palygorskite mostly occurred in the soils of dry areas with higher temperature throughout the province. This mineral was not present in the more humid areas of the province. Besides, palygoskite was found to be dominant in the soils derived from the Qom Formation, as well as Lower and Upper Red Formations belonging to Miocene and Pliocene. It seems, therefore, that the parent material plays a major role in entering palygoskite to the soil system, while the dry climate mostly guarantees the stability of this clay minerals and, to some extent, its limited neoformation in such soils. Both illite and chlorite occur in all soils throughout the province, regardless of their climate, following no particular trend. This may indicate that parent materials play a major role in the occurrence of these minerals. Both climate and parent material appear to have affected the distribution of expandable clays in the soils. In more humid areas of the province (west and southwest), climate plays a larger role in the distribution of this mineral. In other areas of the study region, especially in the eastern parts of the province with a much drier climate, the role of the parent material on the dominant soil clay minerals is more pronounced.
\end{abstract}

Keywords: Palygorskite, Isfahan Province soils, Clay minerals, Chlorite

1. Soil Science Department, College of Agriculture, Isfahan University of Technology, Isfahan, Iran. 84156-83111.

*: Corresponding author, Email: $\underline{\text { f.khayamim } @ \text { alumni.iut.ac.ir }}$ 